\title{
Evaluation of the
}

Three Mile Island Unit 2 Reactor Building Decontamination Process

Prepared by D. Dougherty, J. W. Adams

Brookhaven National Laboratory

Prepared for

U.S. Nuclear Regulatory

Commission

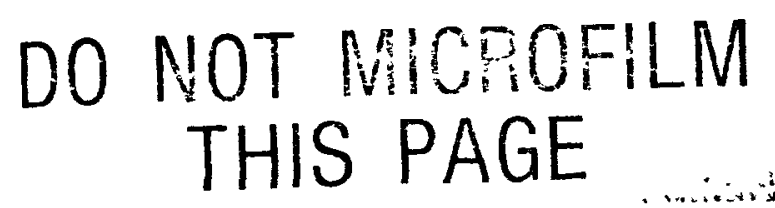




\section{NOTICE}

This report was prepared as an account of work sponsored by an agency of the United States Government. Neither the United States Government nor any agency thereof, or any of their employees, makes any warranty, expressed or implied, or assumes any legal liability of responsibility for any third party's use, or the results of such use, of any information, apparatus, product or process disclosed in this report, or represents that its use by such third party would not infringe privately owned rights.

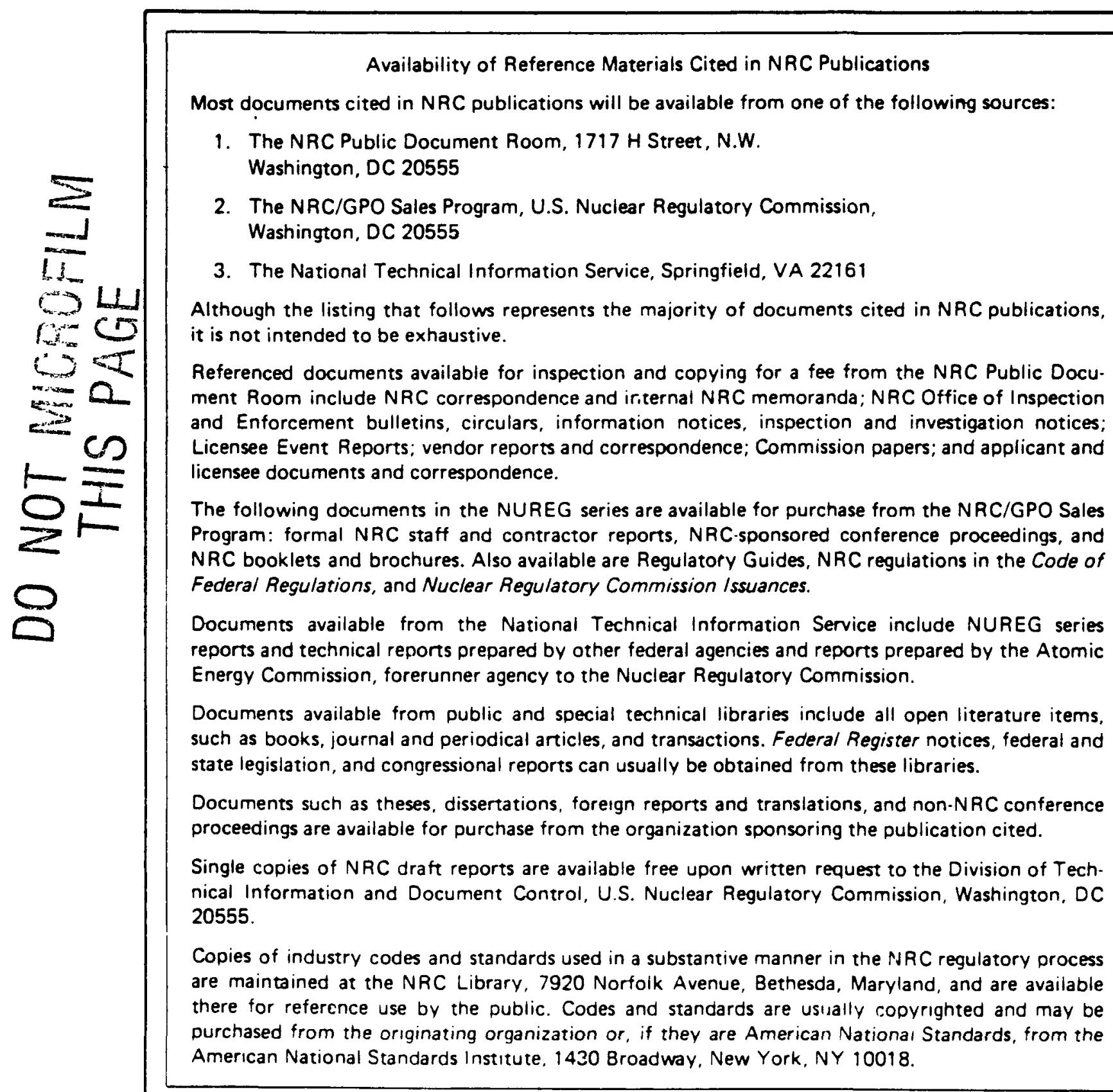

GPO Printed copy price $\$ 4.50$ 


\section{DISCLAIMER}

This report was prepared as an account of work sponsored by an agency of the United States Government. Neither the United States Government nor any agency Thereof, nor any of their employees, makes any warranty, express or implied, or assumes any legal liability or responsibility for the accuracy, completeness, or usefulness of any information, apparatus, product, or process disclosed, or represents that its use would not infringe privately owned rights. Reference herein to any specific commercial product, process, or service by trade name, trademark, manufacturer, or otherwise does not necessarily constitute or imply its endorsement, recommendation, or favoring by the United States Government or any agency thereof. The views and opinions of authors expressed herein do not necessarily state or reflect those of the United States Government or any agency thereof. 


\section{DISCLAIMER}

Portions of this document may be illegible in electronic image products. Images are produced from the best available original document. 


\section{Evaluation of the Three Mile Island Unit 2 Reactor Building Decontamination Process}

NIUREG/CR--3381

DE83 017360

Manuscript Completed: May 1983

Date Published: August 1983

Prepared by

D. Dougherty, J. W. Adams

Brookhaven National Laboratory

Department of Nuclear Energy

Upton, NY 11973

MoTice

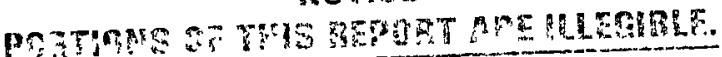

\section{Prepared for}

Division of Waste Management

Office of Nuclear Material Safety and Safeguards

U.S. Nuclear Regulatory Commission

Washington, D.C. 20555

NRC FIN A3162

\section{DISCLAIMER}

This report was prepared as an account of work sponsored by an agency of the United States Government. Neither the United States Government nor any agency thereof, nor any of their exployees, makes any warranty, express or implied, or assumes any legal liability or responsibility for the accuracy, completeness, or usefulness of any information, apparatus, product, or process disclosed, or represents that its use would not infringe privately owned rights. Reference herein to any specific commercial product, process, or service by trade name, trademark, manufacturer, or otherwise does not necessarily constitute or imply its endorsement, recommendation, or favoring by the United States Government or any agency thereof. The views and opinions of authors expressed herein do not necessarily state or reflect those of the United States Government or any agency thereof.

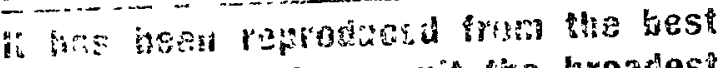
avainate copy to parmit the broadest possibie availability. 


\section{NOTICE}

This report was prepared as an account of work sponsored by an agency of the United States Government. Neither the United States Government nor any agency thereof, or any of their employees, makes any warranty, expressed or implied, or assumes any legal liability of responsibility for any third party's use, or the results of such use, of any information, apparatus, product or process disclosed in this report, or represents that its use by such third party would not infringe privately owned rights.

\section{Availability of Reference Materials Cited in NRC Publications}

Most documents cited in NRC publications will be available from one of the following sources:

1. The NRC Public Document Room, 1717 H Street, N.W. Washington, DC 20555

2. The NRC/GPO Sales Program, U.S. Nuclear Regulatory Commission, Washington, DC 20555

3. The National Technical Information Service, Springfield, ,VA 22161

Although the listing that follows represents the majority of documents cited in NRC publications, it is not intended to be exhaustive.

Referenced documents available for inspection and copying for a fee from the NRC'Public Document Room include NRC correspondence and iriternal NRC memoranda; NRC Office of Inspection and Enforcement bulletins, circulars, information notices, inspection and investigation notices; Licensee Event Reports; vendor reports and correspondence; Commission papers; and applicant and licensee documents and correspondence.

The following documents in the NUREG series are available for purchase from the NRC/GPO Sales Program: formal NRC staff and contractor reports, NRC-sponsored conference proceedings, and NRC booklets and brochures. Also available are Regulatory Guides, NRC regulations in the Code of Federal Regulations, and Nuclear Regulatory Commission Issuances.

Documents available from the National Technical Information Service include NUREG series reports and technical reports prepared by other federal agencies and reports prepared by the Atomic Energy Commission, forerunner agency to the Nuclear Regulatory Commission.

Documents available from public and special technical libraries include all open literature items, such as books, journal and periodical articles, and transactions. Federal Register notices, federal and state legislation, and congressional reports can usually be obtained from these libraries.

Documents such as theses, dissertations, foreign reports and translations, and non-NRC conference proceedings are available for purchase from the organization sponsoring the publication cited.

Single copies of NRC draft reports are available free upon written request to the Division of Technical Information and Document Control, U.S. Nuclear Regulatory Commission, Washington, DC 20555.

Copies of industry codes and standards used in a substantive manner in the NRC regulatory process are maintained at the NRC Library, 7920 Norfolk Avenue, Bethesda, Maryland, and are available there for reference use by the public. Codes and standards are usually copyrighted and may be purchased from the originating organization or, if they are American National Standards, from the American National Standards institute, 1430 Broadway. New York, NY 10018.

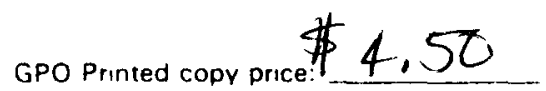




\section{ABS TRACT}

Decontamination activities from the cleanup of the Three Mile Island Unit 2 Reactor Building are generating a variety of waste streams. Solid wastes being disposed of in commercial shallow land burial include trash and rubbish, ion-exchange resins (Epicor-II) and strippable coatings.

The radwaste streams arising from cleanup activities currently under way are characterized and classified under the waste classification scheme of 10 CFR Part 61. It appears that much of the Epicor-II ion-exchange resin being disposed of in commerical land burial will be Class $B$ and require stabilization if current radionuclide loading practices continue to be followed. Some of the trash and rubbish from the cleanup of the reactor building so far would be Class $B$.

Strippable coatings being used at TMI-2 were tested for leachability of radionuclides and chelating agents, themal stability, radiation stability, stability under immersion and biodegradability. Actual coating samples from reactor building decontamination testing were evaluated for radionuclide leaching and biodegradation. Results indicated that both radionuclide contamination and chelating agents leach from strippable coating waste. It swells and partially dissolves upon immersion in water and organic liquids, biodegrades readily in soil and, upon irradiation, generates gas, principally hydrogen. The coating is thermally stable up to at least $100^{\circ} \mathrm{C}$ and is not an unacceptable flame and smoke hazard. The strippable coating samples from the TMI-2 reactor building decontamination testing contained significant strontium-90 and cesium-137 rontamination and would be Class B under 10 CFR Part 61. 
CONTENTS

ABSTRACT. . . . . . . . . . . . . . . . . . . . . . iii

CONTENTS. . . . . . . . . . . . . . . . . . . . . v

FIGURES . . . . . . . . . . . . . . . . . . . . . . . . . vi

TABLES. . . . . . . . . . . . . . . . . . . . . . . . . . vii

ACKNOWLEDGMENTS . . . . . . . . . . . . . . . . . . . . . . . ix

1. INTRODUCTION. • . . . . . . . . . . . . . . . . . . . . . . 1

2. WASTE MANAGEMENT AT TMI-2 REACTOR BUILDING ClFANUP. . • . • . . . . 7

2.1 Reactor Building Decontamination Planning. . . . . . . . . 7

2.2 Decontamination Wastes . . . . . . . . . . . . . . . 7

3. STRIPPABLE COATINGS - GENERAL . . . . . . . . . . . . . . . . 13

3.1 Introduction . . . . . . . . . . . . . . . . . . 13

3.2 Description. . . . . . . . . . . . . . . . . 13

4. STRIPPABLE COATINGS AT TMI. . . . . . . . . . . . . . . . 15

4.1 Introduction . . . . . . . . . . . . . . . . . 15

4.2 Testing ALARA 1146 Strippable Coating for Characterization as

Radwaste . . . . . . . . . . . . . . . 15

4.2.1 Scoping Tests................... 16

4.2.2 Testing of Strippable Coating From TMI-2. . . . . . 34

5. REFERENCES. . . . . . . . . . . . . . . . . . . . . 47

APPENDIX A - 10 CFR PART 61.55: RADIOACTIVE WASTE CLASSIFICATION FOR DISPOSAL IN SHALLOW LAND BURIAL. . . . . . . . . . . 51

APPENDIX B - TECHNICAL DATA SHEET FOR ALARA 1146 DECON STRIPPABLE COATING. • . . . . . . . . . . . . . . . . . . . .

APPENDIX C - CUMULATIVE DOSE CALCULATIONS FOR THE ALARA 1146 STRIPPABLE COATING SAMPLES FROM THE TMI-2 REACTOR BUILDING GROSS DECONTAMINATION EXPERIMENT 
FIGURES

1.1 Vertical Cross-Sectional Schematic of the TMI-2 Reactor Building Showing the Floor Levels in Comparison to the Major Components of the Nuclear Steam Supply System . . . . . . . . . . . . . . 3

4.1 Percent Activity Loss vs Time for Imperial 1146 Strippable Coating Leached in Deionized Water. . . . . . . . . . . . . . . 17

4.2 Percent Weight Gain of ALARA 1146 Strippable Coating Upon Immersion in Toluene, Xylene, Water, and a Solution of Water Saturated With Toluene and Xylene...................... 20

4.3 Weight Gain of ALARA 1146 Strippable Coating Upon Immersion in LSC Cocktail. . . . . . . . . . . . . . . . . . . . 21

4.4 Drying Curves at Room Temperature in Air for ALARA 1146 Strippable Coating Following 34 Days Immersion in Toluene, Xylene, Water, and a Water Solution Saturated With Toluene and Xylene. . . . . . . . . 22

4.5 Drying Curve at Room Temperature in Air for ALARA 1146 Strippable Coating Following 34 Days Immersion in LSC Cocktail . . . . . . . . . 23

4.6 Biodegradative $\mathrm{CO}_{2}$ Gas Evoluation From Scoping Tests on Imperial 1146 Coating in Barnwell and Hanford Solls. . . . . . . . . . . . 25

4.7 Plot of Gas Generation vs Co-60 Gamma Dose for ALARA 1146 Strippable Coating . . . . . . . . . . . . . . . . . . . . . 29

4.8 Effect of Radiolysis on ALARA 1146 Coating vs Unirradiated Specimen • 31

4.9 Leach Test Results for TMI Strippable Coating . . . . . . . . . . . 37

4.10 Biodegradative $\mathrm{CO}_{2}$ Gas Evolution From TMI Strippable Coating Material in Barnwell and Hanford Solls. . . . . . . . . . . . 41

4.11 Probable Range of Biodegradation of TMI Strippable Coating in Barnwell Soll . . . . . . . . . . . . . . . . . 42

4.12 Probable Range of Biodegradation of TMI Strippable Coating in Hanford Soil...................... . 43 
4.1 Immersion and Drying Data for ALARA 1146 Strippable Coating. . . . 23

4.2 Scoping Test Results on the Biodegradation of ALARA 1146 Strippable Coating in Soils From the Barnwell, SC, and Hanford, WA,

Shallow Land Burial Sites. . . . . . . . . . . . . . . . 26

4.3 Gas Composition Analysis From Co-60 Gamma Irradiation Tests of ALARA 1146 Strippable Coating in Air and Under Vacuum. . . . . . . 30

4.4 Gas Analysis From the Thermal Testing of ALARA 1146 strippable Coating. . . . . . . . . . . . . . . . . . . . 33

4.5 Strippable Coating Samples From the TMI-2 Reactor Building Gross Decontamination Testing. . . . . . . . . . . . . . . .

4.6 Activity Distribution Between Leachate and Coating for a Sample Coating From the TMI-2 Gross Decontamination Experiment. . . . . 38

4.7 The Estimated Activities of $\mathrm{Cs}-137$ and $\mathrm{Sr}-90$ in the Five TMI Coating Pleces Considered as a Batch . . . . . . . . . . . . . 39

4.8 Biodegradation Test Results for Strippable Coating Samples From the TMI-2 Reactor Building Gross Decontamination Experiment. . . . 40

C.1 Nuclides and Relevant Decay Data Used in Calculation of Dose to Strippable Coating . . . . . . . . . . . . . . . . . . . .

C.2 Total Absorbed Dose Calculations for the ALARA 1146 Strippable Coating Samples From the TMI-2 Reactor Building Gross Decontamination Experiment . . . . . . . . . . . . . . 



\section{ACKNOWLEDGMENTS}

The authors thank Drs. Richard E. Davis, Robert E. Barletta, and Kar1 J. Swyler for helpful discussions during the course of this work. We also thank $\mathrm{Mr}$. James D. Smith and James Clinton for their technical assistance with experimental portions of this work. Special thanks are due to Ms. Colleen E. Shea without whose assistance and advice the biodegradation portions of this work would have been sparse indeed.

We also acknowledge with sincere appreciation the efforts of Ms. Nancy Yerry and Ms. Kathy Becker for the preparation of this manuscript. 

EVALUATION OF THE THREE MILE ISLAND UNIT 2

REACTOR BUILDING DECONTAMINATION PROCESS

\section{INTRODUCTION}

It has been more than 3-1/2 years since the March 28, 1979 accident at the Three Mile Island Unit 2 Nuclear Generating Plant which left the reactor core damaged and the reactor building contaminated with fission products. During this time plans $(1-7)$ have been made and effort $(8-12)$ expended to cleanup and recover TMI-2. These efforts are directed toward decontaminating the reactor building, removing the nuclear fuel from the damaged core and decontaminating the reactor coolant system and connected systems. Decontamination of the reactor building will initially focus on those areas needed for defueling. These areas, as shown in Figure 1.1, include the 305-ft. level, the 347-ft. level (the operating floor) and the polar crane. The reactor coolant system water must also be cleaned up to reduce the concentration of dissolved fission products prior to defueling.

Major milestones(13) in the cleanup and recovery effort have included the following events:

(1) Venting to atmosphere of the 44,000 Curies of the fission product gas krypton-85 which was released in the reactor building during the accident. This was done between June 28 and July $11,1980$.

(2) Removal of dissolved fission product activity from the 565,224-gal of tritiated accident water in the Auxiliary and Fue1-Handling Building (AFHB). The fission product activity was removed by ion exchange (Epicor II $^{*}$ ) between November 1979 and December 1980. The highly loaded ion-exchange resins are being transferred to the Department of Energy (DOE) for disposal. The tritiated accident water $\left(<1 \mu \mathrm{Ci} / \mathrm{cm}^{3}\right)$ is being stored for reuse at TMI.

(3) Removal of the dissolved fission product activity from more than $600,000 \mathrm{gal}$ of tritiated accident water which flooded the basement (282-ft elevation) of the reactor building. The fission product activity was sorbed onto zeolite demineralizer beds in the Submerged Demineralizer System (SDS) between September 23, 1981 and March 5, 1982. The tritiated water effluent from the SDS was polished (i.e., the small amount of fission product activity not sorbed onto the zeolites, was removed) using Epicor-II ion-exchange resin. The highly loaded zeolites are being transferred to DOE for disposal. Activity levels in the Epicor-II polishing resins were within the Hanford, Washington, commercial land burial site limit $(<1 \mu \mathrm{Ci} / \mathrm{g})$

\footnotetext{
*Proprietary ion-exchange system of Epicor, Incorporated.
} 
for disposal in the dewatered form and without solidification. The tritiated accident water $\left(<1 \mu \mathrm{Ci} / \mathrm{cm}^{3}\right)$ is being stored for reuse at TMI.

(4) The Gross Decontamination Experiment was performed between October 29, 1981 and March 26, 1982. This effort was directed toward reducing radiation levels on the 305-ft. elevation and above and toward determining the relative decontamination effectiveness of the several techniques selected for testing.

(5) Gross Decontamination of the reactor building including the 305-ft. elevation and above started September 17, 1982. The effort was designed to reduce smearable levels of contamination to the point that workers will be able to remove much of the bulky protective clothing and the respirators.

(6) Removal of fission product activity from the 88,000 gallons of water in the reactor coolant system ( $R C S$ ) using the SDS has been attempted but has not been completely successful. Strontium-90 from the fue 1 debris apparently is dissolving into the cleaned water and restoring the strontium-90 activity to near its initial level. This phenomenon may influence the RCS cleanup plans which were not finalized as of this writing.

Major events(12-16) in the cleamp and recovery yet to occur include:

(7) Defueling of the reactor. Plans for removing the fuel from the reactor await detailed inspection of the core. This inspection began with the "Quick Looks" $(13,14)$ into the reactor vessel with a remote TV camera and will continue when the reactor vessel head is removed, which is scheduled for sometime in mid 1983. It is hoped that fuel removal from the core can be completed by late 1985. (15)

(8) Decontamination of the reactor coolant systein and connected systems which have been contaminated by fuel debris. The decontamination techniques and procedures to be used for this cleanup will not be decided upon until studies being performed by the Electric Power Research Institute (EPRI) recommend appropriate techniques. (12)

(9) Cleanup of the refueling canal during and after reactor defueling. Transfer of the core debris from the reactor to a packaging facility may result in substantial soluble and particulate contamination of the refueling canal.

(10) Hands-on decontamination of the 305-ft. elevation and above. This is intended to return the working environment in this part of the reactor building to near nomal (i.e., pre-accident) conditions. This effort will start sometime after Gross Decontamination, Item 5. 
347' Elevation Floor

Refueling Canal

305' Elevation Floor

282' Elevation Floor

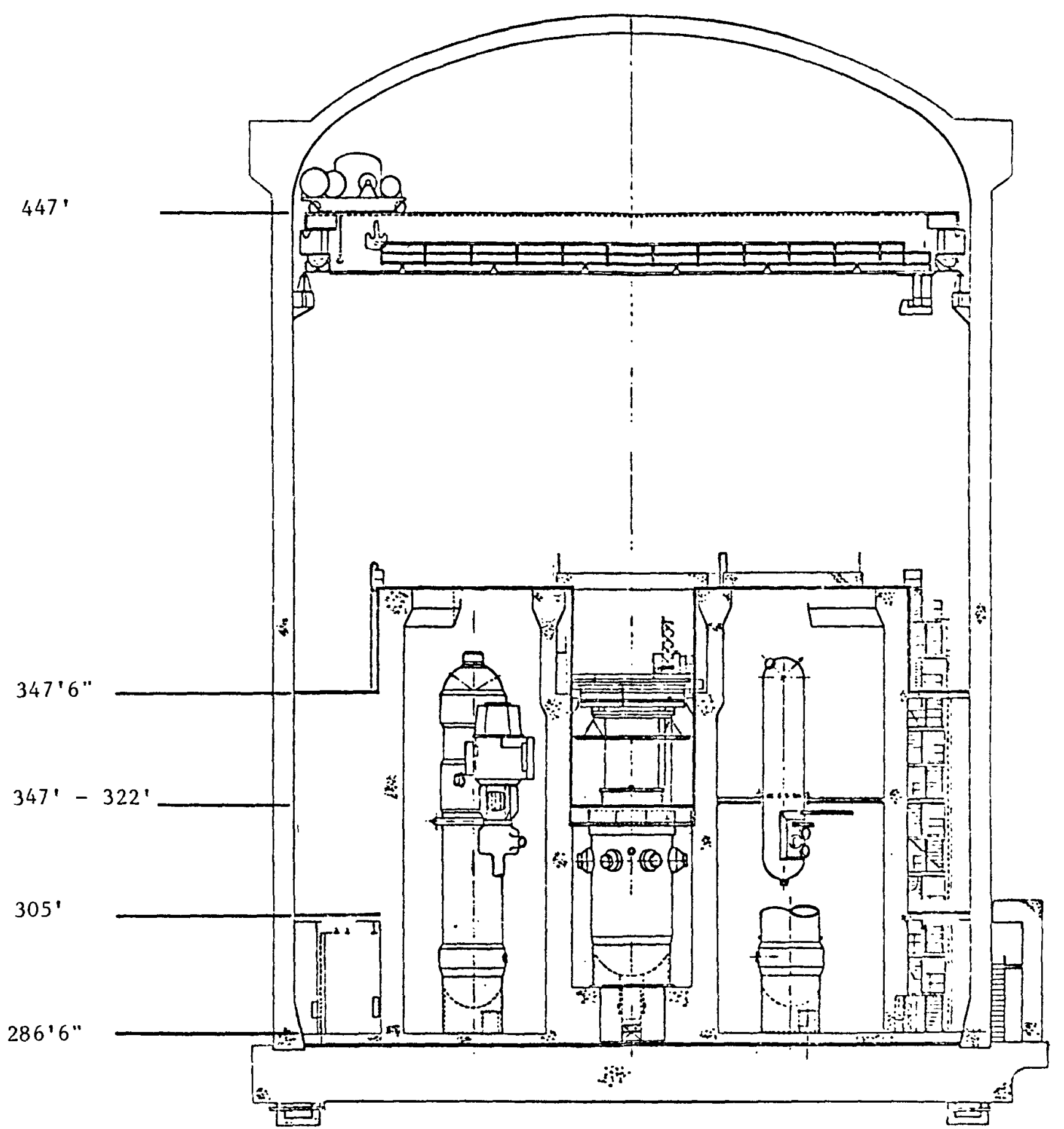

Figure 1.1 Vertical cross-sectional schematic of the TMI-2 reactor building showing the floor levels in comparison to the major components of the nuclear steam supply system. 
(11) Decontamination of the 282-ft. evaluation. The 600,000 gallons of highly contaminated water, Item 3, filled this part of the reactor to a depth of about $8 \mathrm{ft}$. This elevation has much higher radiation fields than the upper portions of the reactor building.

(12) Disposal of the more than 1-million gallons of tritlated accident water, Items 2 and 3 . TMI is under specific NRC order(16) not to release any of the accident water. In addition to the considerations of $10 \mathrm{CFR}$ Part 20 with regard to this water, the NRC and the State of Maryland are conducting studies on potential socioeconomic impacts of various alternatives for disposal of the accident water.

Flushing with both low and high pressure water spray has been the principal decontamination method for removal of as much loose debris and smearable and soluble activity as possible. The tritiated accident water $(<1 \mu \mathrm{Ci} \mathrm{H}-3$ per $\mathrm{mL}$ ) is being used for the water flushing decontamination activity. It is routed through floor drains from the upper levels in the reactor building to the basement (282-ft. elevation) from where it is then sent to the SDS for cleanup and return to tank storage for reuse. The Gross Decontamination Experiment (GDE) also tested, in small scale, detergent (Turco $4324 \mathrm{NP}-10 \%$ ) and phosphoric acid (Turco 4512-A 10\% Normal) solutions in conjunction with a floor scrubber.(10) These tests were conducted on two $128 \mathrm{ft}^{2}$ areas, one for each solution, on the floor of the 347-ft elevation. The liquid wastes, approximately 26 gallons for each solution, were wet vacummed into 55-gal drums and then transferred to storage. The storage container is an 8000-gal tank at TMI in which all liquid wastes are combined for storage. Strippable coatings were also tested during the GDE. These coatings are applied as liquids. After drying to a rubbery film, the coatings are then peeled of $f$ for disposal. This results in only solid waste which is then drumed for disposal. Problems associated with the processing of radioactive waste produced by decontamination methods other than water flushing have provided a major inhibition to their use at TMI-2.

The cleanup activities listed above are generating a large quantity of radioactive waste. Some of this waste is unique - such as the damaged core. Some of the waste contains exceptionally large amounts of activity and is not suitable for disposal in commercial land burial. Disposal of these wastes is provided for in the Memorandum of Understanding (17) (MOU) between the NRC and the Department of Energy (DOE). The MOU states that DOE may, on an $R$ and $D$ or reimbursable basis, take posession of the nuclear fuel and those radioactive wastes from TMI-2 which are not suitable for disposal in commercial land burial. However, a large amount of waste will go to commercial land burial. $(18,19)$

The radionuclides of concern in the cleanup wastes are long-lived fission products - principa1ly Cs-137 and Sr-90, rather than neutron activation products (e.g., Co-60) associated with reactor "crud". Fuel debris from the reactor core will also contain transuranic (TRU) contamination. In wastes from 
cleanup of the RCS and possibly the 282-ft elevation, the TRU contamination may be of most concern. The strippable coatings being used in the cleanup contain chelating agents.

Since the cleanup of TMI-2 will continue well into the latter half of the decade, much of the waste generated will fall under the regulation of 10 CFR Part 61, "Licensing Requirements for Land Disposal of Radioactive Waste." The activities of alpha-emitting TRU and the long-lived fission products Cs-137 and $\mathrm{Sr}-90$ are used in 10 CFR Part 61 to classify radwaste for disposal purposes. The waste classification section of the regulation, 10 CFR Part 61.55, is attached as Appendix A. The NRC has contracted Brookhaven National Laboratory (BNL) under FIN A-3162, Task 7, "Evaluation of the Three Nile Island Unit 2 Reactor Building Decontamination Process," for technical assistance in characterizing these decontamination wastes. Evaluation of the strippable coatings being used in the decontamination effort is specifically included in this task. Evaluation of these wastes for compliance with the provisions of 10 CFR Part 61 is a part of this characterization.

The decontamination wastes being generated in the cleanup of the TMI-2 reactor building, as of this writing, are described and their performance under 10 CFR Part 61 is evaluated. Strippable coating properties and uses are presented along with the results of testing for radionuclide and chelating. agent leachability, thermal stability, biodegradability, and radiation stability. The activity that strippable coating waste from TMI-2 may contain are estimated from samples of coating from the Gross Decontamination Experiment. 



\section{WASTE MANAGEMENT FOR TMI-2 REACTOR BUILDING CLEANUP}

\subsection{Reactor Building Decontamination Planning}

Reactor building decontamination planning is based on the alternatives outlined in the Final Programmatic Environmental Impact Statement (PEIS). $(3,16)$ The specific technologies chosen have been based on effectiveness, waste management, and other considerations. The approximately chronological listing in Section 1 of major events in the TMI-2 cleanup also provides a basis for categorizing the various streams of radioactive waste being generated in the reactor building cleanup. Items 1-4 have been completed and item 5 is scheduled for completion no later than the end of January, 1983.*

\subsection{Decontamination Wastes}

Waste stream characterization for various decontamination and waste processing alternatives has been estimated in some detail in the PEIS. (3) The wastes generated from the activities of Items 2 and 3 , Section 1, consisted of SDS zeolites, Epicor-II lon-exchange resins, and general trash. The SDS zeolite waste and the Epicor-II vaste were highly radioactive and DOE has agreed to take possession of these under the MOU. An estimate of the Classification that these wastes would have had under 10 CFR Part 61 (draft version) is available.(20) DOE is using some of the Epicor-II wastes, Item 2, and the zeolite wastes, Item 3 , in various research programs related to radioactive waste and the rest is being disposed of as "special waste" on a one-time disposal basis. $(20,21)$ The entire reactor core from the defueling operation, Item 7 , will be taken by DOE. (17) Wastes contaminated by TRU concentrations in excess of the levels authorized for commercial burial may also be accepted by DOE. (17) Some wastes from (Section 1) Items 8, 9, and 11, may be transferred to DOE under the MOU provision cited in the preceeding sentence. The TMI-2 licensee, General Public Utilities, is disposing of the low level waste arising from the cleanup operations at the Hanford, Washington, commercial radioacitve waste land burial site.(18) The waste being shipped to the Hanford commercial burial site is similar to wastes being routinely generated at other nuclear power facilities.

Characterization of TMI-2 radwaste is accomplished using gamma measurements from which radionuclide inventories are estimated. $(22,23)$ Two categories of radwaste have been defined in the reactor building cleanup so far: (1) Normal Unit-2 radwaste and (2) Makeup and purification (MUP) system radwaste. Normal Unit-2 radwaste is being generated by cleanup activities on the 305-ft elevation and above. The activity in normal unit 2 radwaste has a specified fractional composition of $0.471 \mathrm{Cs}-137$ and $0.0234 \mathrm{Sr}-90$. The remainder consists of the $\mathrm{Ba}-137 \mathrm{~m}$ and $\mathrm{Y}-90$ daughters of $\mathrm{Cs}-137$ and $\mathrm{Sr}-90$ plus some Cs-134. The MUP system, which is located on the $281-\mathrm{ft}$ level of the $\mathrm{AFHB}$, consists of ion exchange resin bed demineralizers and heat exchangers.

\footnotetext{
*Personal communication between D. Dougherty (BNL) and D. Geifer, Bechtel National Corporation, at TMI, December 14, 1982.
} 
This system is connected directly to the reactor coolant system. It is scheduled to be decontaminated as part of the RCS cleanup. As of this writing no MUP radwaste has been generated. MUP radwaste has been specified to have the following isotopic fractional distribution: $0.176 \mathrm{Cs}-137,0.234 \mathrm{Sr}-90$, and plus $2.74 \times 10^{-4}$ TRU. The TRU content limits the fission product activity in a container to avoid exceeding the $10 \mathrm{nCi} / \mathrm{g}$ limtt imposed by the Hanford burial site. The container activity limits necessary to avold exceeding the TRU limit of $10 \mathrm{nCi} / \mathrm{g}$ are listed in Reference 22. The activity inventory in a waste container is estimated for both categories of radwaste using the following equation,

\section{Container Activity $(\mathrm{mCi})=(\mathrm{C} . \mathrm{F}$.$) (Average Measured Dose Rate [\mathrm{mrem} / \mathrm{h}])$}

in which C.F. is a conversion factor which depends on the container and whether the activity in the waste is normal or MUP. Three types of containers, each with its own C.F., are used at TMI-2 for solid waste disposal. These are compacted and non-compacted 55-gal drums and $98 \mathrm{ft}^{3}$ LSA boxes.

Volume reduction capability for solid radwaste at TMI-2 consists of a 30,000 psi compactor for 55-gal drums as of the writing of this report. A 5-gph evaporator is available for liquid wastes but, as of this writing, has never been used.(12) This small evaporator was to be tested on chemical decontamination liquids but there were no plans to place the evaporator in service in the foreseeable future.* There is no solidification facility at TMI-2. A facility for solidifying waste in cement is available at TMI-1, but it is not allowed to be used for TMI-2 wastes. A 30-gph evaporator was considered for installation in 1979, but has not been purchased. Incineration was also a considered option for volume reduction, but an incinerator has not been purchased. $(12,24)$

Solid waste is packaged in 55-gal drums and 98-cu. ft. L.S.A. boxes for storage, shipment, and disposal. Compactible wastes can be volume reduced by compaction into 55-gal drums. As a general rule, compaction of waste is performed to the maximum extent possible. However, waste that would exceed the LSA classification under compaction and waste whose activity is such that the compactor operators would receive too large a dose are not compacted. That waste suitable for land burial is shipped to Hanford, Washington, conmerical burial site for disposal(18) in placarded, exclusive use trucks. Shipments are now averaging about two per month** although they were more frequent when radwaste shipments from TMI-2 started in November 1979. A ful1y loaded trailer holds 20 LSA boxes (1960 $\mathrm{ft}^{3}$ ) or approximately 150, 55-gal drums $\left(1100 \mathrm{ft}^{3}\right)$ or a mixture of the two. TMI shipment number Rs-82-028-II, April 29, 1982, may be representative of typical radwaste shipments from

\footnotetext{
*Personal communication between D. Dougherty (BNL) and P. Carmel (Bechte1) at TMI, December 17, 1982 .

${ }^{* *}$ Personal communication between $D$. Dougherty (BNL) and T. Moslak (NRC) at TMI, September 8, 1982 .
} 
TMI-2.* This shipment contained 6 LSA boxes and 68 drums. Five of these drums labelled "compacted trash" would be Class B under 10 CFR Part 61 for the Sr-90 content or the Sr-90 plus Cs-137 content.

Gross decontamination of the 347-ft elevation was performed with water spray and a mechanical floor scrubber using a non-abrasive pad and water. The contaminated water is cleaned up using the SDS and Epicor-II systems. The activity loading of the zeolites in the SDS from this cleanup is not known. The activity loading of the Epicor-II resins is determined by monitoring activity levels of the influent to and effluent from the Epicor-II system. The loading is limited to $<1 \mu \mathrm{Ci} / \mathrm{g}$. The Hanford license** states that resins having activities less than $1 \mu \mathrm{Cl} / \mathrm{cm}^{3}$ with half-1ives greater than 5 years can be disposed of in the dewatered condition. Since dewatered Epicor-II resin has an apparent density of approximately $0.7 \mathrm{~g} / \mathrm{cm}^{3}$, the $1 \mu \mathrm{Cl} / \mathrm{g} 1$ oading at TMI is below that allowed by Hanford ( $1 . \mathrm{e}, 1 \mu \mathrm{Ci} / \mathrm{cm}^{3} \div 0.7 \mathrm{~g} / \mathrm{cm}^{3}=$ $1.4 \mu \mathrm{Cl} / \mathrm{g})$. Hence, spent resins have been dewatered and shipped to Hanford for disposal.

The Epicor-II system for polishing the SDS effluent has three sections: the pre-filter stage ( $P F)$, the first stage ( $K$ filter) and the second stage ( $2 \mathrm{~K}$ filter). Through 1982 42-PFs, 8-K and 7-2K filters had been used.*** of these totals 23-PFs, 5-Ks and 6-2Ks were stored at TMI awaiting disposal. The PFs were loaded to approximately $1 \mu \mathrm{Cl} / \mathrm{g}$ while the $\mathrm{K}$ and $2 \mathrm{~K}$ filters were loaded to lesser activities. PFs are shipped in shielded casks for disposal, $2 \mathrm{~K}$ filters do not require shielding for shipment and $\mathrm{K}$ filters are shielded or not on a case by case basis. Disposal costs have led to studies of the cost effectiveness of continuing present procedures. An alternative currently being considered is to increase the activity loading on the Epicor-II resins followed by solidification prior to disposal.****

By way of illustration, the 10 CFR 61 classifications that Epicor-II radwaste would have if loaded to $1 \mathrm{\mu Ci} / \mathrm{g}$ with activity of Normal Unit-2 and MUP radioisotopic fractional compositions are calculated. The fractional activities of $\mathrm{Cs}-137$ and Sr-90 in Normal Unit-2 Radwaste are 0.471 and 0.0234 , respectively. The cumulative fraction under 10 CFR Part 61 from Table 2 of Appendix A, using the gravimetric loading limit of $1 \mu \mathrm{Ci} / \mathrm{g}$ and the apparent

\footnotetext{
${ }^{*}$ Copies of the shipping papers for this shipment were forwarded to BNL from a request for information on a typical solid waste shipment for commercial land burial.

** The State of Washington, Radioactive Materials License $W N-I 019-2$, Amendment No. 15 in accordance with renewal application dated Dctober 28, 1981, expiration date November 30, 1985.

*** Personal communication between D. Dougherty (BNL) and T. Moslak (NRC) at TMI, December 17, 1982 .

**** Personal communication between $D$. Dougherty (BNL) and $R$. Hahn (GPU) at TMI, April 27, 1983.
} 
density of approximately $0.7 \mathrm{~g} / \mathrm{cm}^{3}$ for dewatered Epicor-II resin is

$\frac{0.471}{1.0 \mu \mathrm{Ci} / \mathrm{cm}^{3}} \times 1 \mu \mathrm{Ci} / \mathrm{g} \times 0.7 \mathrm{~g} / \mathrm{cm}^{3}+\frac{0.0234}{0.04 \mu \mathrm{Ci} / \mathrm{cm}^{3}} \times 1 \mu \mathrm{Ci} / \mathrm{g} \times 0.7 \mathrm{~g} / \mathrm{cm}^{3}=0.74$

Performing the same calculation using the MUP radwaste fractional contents for $\mathrm{Sr}-90$ and $\mathrm{Cs}-137$ leads to a value of 4.2 . These numbers mean that if the radionuclide fractional compositions in normal and MUP radwaste are carried through in the SDS effluent to the Epicor-II system, then a $1 \mu \mathrm{Ci} / \mathrm{g}$ loading would be Class $A$ for the normal Unit-2 radwaste radionuclide composition and Class $B$ for the MUP fractional distribution. In actuality, any radionuclide composition effluent from the SDS has a larger strontium fraction than the influent. This is because cesium is held up on the SDS demineralizer beds much more than is strontium, as shown by the SDS data presented in Table I and Figure 3, Reference 11. Specifically, the decontamination factors 11sted in Table I, Reference 11, for processing the reactor building sump water are 140,000 for $\mathrm{Cs}-137$ and 590 for $\mathrm{Sr}-90$. The ratio of $\mathrm{Sr}-90$ to $\mathrm{Cs}-137$ activities in the influent to and effluent from the SDS were 0.04 and 10.2 , respectively. It is therefore likely that all of the Epicor-II resins loaded to even a modest fraction of $1 \mu \mathrm{Ci} / \mathrm{g}$ will be Class $\mathrm{B}$.

Gross decontamination of the 305-ft elevation is being performed with water spray and a mechanical floor scrubber, as was done on the 347-ft level. Phosphoric acid solution (Turco 4512-A 10\%) will also be used on parts of the 305-ft level. The phosphoric acid radwaste solution is to be neutralized and combined with other liquid waste in the holding tank at TMI. Since TMI-2 has no evaporation and solidification facilities for liquid wastes, they are stored. These stored liquid wastes may be solidified by vendors with mobile facilities called in for specific jobs. This was done once as part of a demonstration of the Dow solidification system but there are no specific plans for disposal of the stored liquid wastes as of this writing.

Strippable coatings are being used on some decontaminated sections of the 305- and 347-ft elevations and the polar crane to provide a protective barrier against recontamination. Except for the GDE testing, these coatings have not been used for decontamination on the upper part of the reactor building. These protective layers of coating are scheduled to remain in place until after the reactor head lift which is planned for Spring, 1983. The activity that these coatings contain will depend on both how much contamination they remove from the gross decontaminated surface and how much they receive from contamination of the top surface. The classification of the protective coating waste under 10 CFR Part 61 cannot be reasonably estimated unt 11 it is peeled from the surfaces and assayed prior to disposal.

Cleanup of the RCS water, Item 6 , is generating highly loaded SDS zeolite and pre-filter radwaste. The pre-filters will also contain TRU activity from suspended fuel debris. These wastes will be taken by DOE. 
Items, 7, 8, and 9 are interrelated to the extent that DOE will take the nuclear fuel and may take other TRU contaminated radwaste (in excess of the $10 \mathrm{nCi} / \mathrm{g}$ limit of the Hanford commercial burial site). It is uncertain if DOE will accept wastes having TRU activities in excess of $10 \mathrm{nCl} / \mathrm{g}$. It is also uncertain if the $10 \mathrm{CFR}$ Part $61 \mathrm{TRU}$ limit of $100 \mathrm{nCi} / \mathrm{g}$ (Table 1 , Appendix A) will be applied. Since much of the core has been reduced to rubble, the amount of fuel particulate contamination in radwaste resulting from these cleanup activities may be large. Therefore, SDS pre-filters from these cleanup activities may contain TRU contamination. The SDS zeolites from water cleanup in Items 7,8 , and 9 will be highly loaded with fission products and DOE will take these. Epicor-II pollshing resins are loaded so as not to exceed $1 \mu \mathrm{Cl} / \mathrm{g}$ in the dewatered form. This allows disposal of these wastes at the Hanford commercial disposal site without solidification. When $10 \mathrm{CFR}$ Part 61 takes effect, this resin waste will require solidification if loaded to near $1 \mu \mathrm{Cl} / \mathrm{g}$, as is the practice as of this writing.

The decontamination procedures to be used in the hands on decontamination of the TMI-2 reactor building have not been determined as of this writing. Therefore, the waste streams that will be generated from this activity have not yet been defined. The Gross Decontamination has involved removing smearable contamination without significant surface penetration. There is some evidence that paint removal by abrasion, grit blasting or similar methods may ultimately be needed for complete decontamination. $(8,25)$ Loss of coolant accident (LOCA) tests have shown that epoxy painted surfaces do not decontaminate read11y after a LOCA. (25) Results from the GDE indicate that about $10 \%$ of the contamination remains in epoxy painted surfaces after gross decontamination. The activity remaining in floor surfaces averaged approximately $0.5 \mu \mathrm{Ci} / \mathrm{cm}^{2}$ for Cs isotopes after GDE.(8)

There are no firm plans for the decontamination of the 282-ft elevation, Item 11, as of this writing. The wastes resulting from cleanup of this area of the reactor building are anticipated to contain very high levels of fission product activity and may contain significant TRU activity.

Waste management at TMI-2 is evolving as the waste streams from the various cleanup activities are processed. For wastes to be disposed of by commercial burial, efforts have been made to limit activity to LSA limits. Wastes which do not meet the LSA criterion are stored at TMI since, as of this writing, there are no procedures for packaging and shipping wastes which do not meet the LSA criteria.(26) These non-LSA wastes include some solid waste plus the chemical liquid wastes in holding storage at TMI-2. The liquids may be solidified by contractors brought in for these specific jobs, but this has not been planned as of this writing. 


\section{STRIPPABLE COATINGS - GENERAL}

\subsection{Introduction}

Strippable coatings are film-forming compositions which are applied as liquids and which, after drying, are peeled from the surface. The great advantage of strippable coatings for radioactive decontamination is that only solid waste is produced. They have been found to be useful for removing loose debris and smearable contamination $(9,27-33)$ and for significantly decreasing the level of particulates in the air. (9) The coatings are also useful as a barrier to protect cleaned surfaces from recontamination. If the protective layer is contaninated, it can be removed and replaced or, preferably, a second layer of coating can be applied trapping the contamination betwen two layers of film before stripping. They have also been used to immobilize loose contamination on equipment to allow moving it without spreading contamination.(30) Strippable coatings are most effective on smooth surfaces. Thicker applications, multiple applications, one on top of the other, and/or reinforcement with a matrix, such as cheesecloth, may be required to successfully strip from porous, pitted or corroded surfaces. The coating may not adhere to some surfaces, such as Teflon, or to oily surfaces. Decontamination factors (DF) of 10 are routinely obtained with one application of strippable coating, which compares favorably with DF obtained using liquid decontamination agents. (29)

\subsection{Description}

Chemically, strippable coatings consist of a film forming agent, usually in colloidal suspension, in a solvent. Other chemicals are added to the mixture to improve the decontamination or physical characteristics. Several strippable coating formulations have been described in the literature. One $(31)$ uses polyvinyl alcohol as the filming agent. Another $(28,32)$ uses prevulcanized rubber latex. A fast drying composition(33) uses a solution of copolymers of polyvinyl chloride and vinyl acetate. Although the filming agent alone is effective in removing loose contamination, the addition of chelating agents such as EDTA and NTA can significantly increase the decontamina$t$ ion effectiveness of these formulations. $(28,31,32)$

A typical formulation for polyvinyl alcohol based coatings( 31 ) was given as follows: $2-10 \%$ polyvinyl alcohol in water, $1 \%$ EDTA, $15-20 \%$ ethanol, $0.02 \%$ sodium carbonate and $1-2 \%$ glycerine or ethylene glycol. This formulation consists of only $4-13 \%$ solids with the remainder being solvent which evaporates to leave the rubbery strippable film. The ethanol (optional) is included to aid the wetting of the surface. The sodium carbonate raises the $\mathrm{pH}$ and helps fix ions such as strontium and barium in the set coating. Glycerin or ethylene glycol acts as a plasticiser to keep the texture of set coating elastic and easily peelable from the surface.

The prevulcanized rubber latex strippable coating $(28,32)$ comes in 1 iquid form as an alkali stabilized emulsion with water. The formulation, which 
incorporates an alkaline complexing detergent, is called Detex (for Detergent latex). Fine pumice can be added to Detex to obtain the added benefit of abrasion when the coating is applied with scrubbing.

A fast drying plastic strippable coating of copolymeric polyvinyl chlor1de $(83-85 \%)$ and vinyl acetate $(15-17 \%)$ is claimed to film on contact and to be removable after only 3 minutes drying time. The rapid filming allows this coating to be sprayed onto vertical surfaces without running. However, volatile organic solvents which allow the rapid drying can cause ventilation and flammability problems.

The characteristics that strippable coatings produce on1y solid waste in relatively small volumes and can be used for both decontamination and for protecting clean surfaces make them useful for radioactive decontamination. At least three vendors* in the United States of fer strippable coatings for this use.

\footnotetext{
*Imperial Professional Coatings Incorporated, New Orleans, LA; Turco Products, Carson, CA; RAD Services, Incorporated, Pittsburgh, PA.
} 


\subsection{Introduction}

The strippable coating being used in the cleanup of the TMI-2 reactor building is Imperial* ALARA 1146 Decon. (Two strippable coating formulations -Imperial 1146 and 1148- were tested in the Gross Decontamination Experiment but only the 1146 coating was recommended for use because of problems encountered in stripping the 1148 coating.) Imperial ALARA 1146 Decon is a waterborne, vinyl composition incorporating chelating agents. A technical data sheet, put out by Imperial, on the properties of the 1146 coating is reproduced in Appendix B. The identities and quantities of chelating materials in 1146 are considered proprietary by Imperial. (34) According to the data sheet, the coating decontaminates a surface both physically and chemically; it absorbs and chemically binds heavy metal isotopes while wet and, upon curing, mechanically locks these absorbed contaminants plus smearable and loose contamination into a polymer matrix. It is also claimed to be useful for protecting clean surfaces, for inhibiting airborne contamination and for shielding against beta emitters. (A typical 25-mil thickness of 1146 coating would provide effective shielding for low energy beta emitters, up to approximately $0.3 \mathrm{MeV} .(35)$ However, this 25-mil thickness would be almost completely ineffective for shielding the $2.2 \mathrm{MeV}$ beta electron from the Y-90 daughter of Sr-90.)

Imperial 1146 strippable coating was tested on the floor of 305-ft elevation of the TMI-2 reactor building as part of the Gross Decontamination Experiment (GDE). This surface(1) consists of a concrete substrate finished with $K$ and $L^{* *} 7107$ epoxy primer and $K$ and $L 7475$ epoxy paint. (All of the concrete surfaces in the reactor building are finished with $\mathrm{K}$ and $\mathrm{L} 7107$ and 7475 epoxy primer and paint; reference 1, Table 4.1.) For testing (10) in the GDE, the 1146 coating was applied to an approximately 500- $\mathrm{ft}^{2}$ area of the 305-ft. elevation in the northwest quadrant north of the open stairwell. This application followed low pressure water flushing of the area to remove loose debris and water soluble contamination. A description of this test of the 1146 strippable coating including the volume and an estimation of the activity of the radwaste produced is included in Reference 10. (This information is detailed in Section 4.3 of this report along with other experimental results on TMI strippable coatings from the GDE.)

\subsection{Testing ALARA 1146 Strippable Coating for Characterization as Radwaste}

Tests were performed on ALARA 1146 coating purchased from Imperial Professional Coatings, Incorporated, and on samples of ALARA $1146 \mathrm{from}$ the GDE testing on the 305-ft. elevation floor of the TMI-II reactor building. Characterization of ALARA 1146 is based on test results for leachability of Co,

\footnotetext{
*Imperial Professional Coatings, Incorporated, P.0. Box 2977, New Orleans, LA, 70189.

${ }^{*}$ Keeler and Long, Incorporated, Watertown, CT.
} 
Sr, and Cs radionuclides and chelating agents and on tests for stability toward irradiation, biodegradation, immersion and heat. Scoping test results on the purchased material are presented in Section 4.1 while test results on the samples of the actual TMI-II coating are presented in section 4.2 .

\subsubsection{Scoping Tests}

\subsubsection{Sample Preparation}

Samples of ALARA 1146 coating were prepared according to directions in the technical data sheet, Appendix $B$. The shelf life of liquid coating $\mathrm{mix}$ is 4 months according to Appendix 8. The liquid coating mix was used within 1 month of its arrival in accordance with vendor recommendations. The liquid material was stirred before and during application and was spread evenly over a surface to cure for at least 2 days (full cure) before stripping. The coating was spread with a groved Teflon sheet instead of being sprayed or applied with a roller as is suggested in the technical data sheet. Spraying and rolling were impractical on the laboratory scale of these tests, and as long as the coating is merely spread and not mechanically scrubbed, the method of application should not matter. The surfaces on which the coating was spread included Lucite sheets and small painted forms* of concrete and steel similar to the epoxy painted surfaces in the TMI-II reactor building. The stripped coating used in all of the scoping tests was $18+2$ mils thick. For the radionuclide leach tests, $40 \mathrm{~mL}$ of coating mix was spiked with $0.2 \mathrm{~mL}$ of an aqueous solution containing $20 \mu \mathrm{Ci} \mathrm{Cs}-137,40 \mu \mathrm{Ci} \mathrm{Sr}-85$ and $40 \mu \mathrm{Ci} \mathrm{Co}-60$. Spiked samples for leach testing were prepared this way rather than by contaminating the surfaces with the spike, allowing it to dry and then applying the coating in order to avoid contamination of the painted samples and to prepare the contaminated coating such that the activity would be held in the coating as firmly as possible. This would then provide radionuclide leach data which should be a measure of the best performance (i.e., lowest leach rates) that could be expected of coating used for actual decontamination. There was no detectable activity remaining on the epoxy painted forms after the coating was stripped indicating that the distribution coefficient between the coating and epoxy painted surfaces is large and in favor of the coating for the radionuclides as tested. The spiked coating mix was stirred for five minutes before being applied to the $K$ and $L$ epoxy painted specimens for cure.

\subsubsection{Radionuclide Leach Testing for Sr, Cs and Co}

Scoping test samples of ALARA 1146 spiked with Cs-137, Sr-85 and Co-60 were prepared as described in Section 4.2.1.1. Half-inch square test specimens - three each from the $K$ and $L$ painted steel and painted concrete

\footnotetext{
* Specimen forms furnished by the Keeler and Long Corporation ( $K$ and $L$ ) included $2 \times 4 \times 1 / 4-i n$. carbon steel coupons primed and painted with $6548 / 7107$ epoxy primer and E-1-7475 epoxy enamel and $2 \times 4 \times 2-i n$. concrete blocks finished with 4129 epoxy concrete curing compound, 6548 S epoxy surfacer and $\mathrm{E}-1-7475$ epoxy enamel.
} 
forms - were cut from the spiked coating which had been peeled from the painted surfaces. These specimens were then leached in $32.3 \mathrm{~mL}$ deionized water for a leachant volume to specimen surface area ratio of $10.0 \mathrm{~cm}$. Leachants were changed and the activity remaining in each of the test specimens was counted at $1,2,3,4,8,9,11,15$, and 18 days. A Geli detector was used for gamma counting. Counts were integrated over 5 or 10 minutes, a decay correction applied for $\mathrm{Sr}-85$, and the measured activity compared to that initially present in the sample. Figure 4.1 shows a plot of leached activity at each of the points of measurement stated above. The activity leached was calculated according to Eq. (4.1) for each isotope.

$$
\text { Activity Leached }(\%)=\sum_{i} \frac{C_{0}-C_{i}}{C_{0}} \times 100
$$

$C_{0}$ and $C_{i}$ are the initial activity and the activity at day $i$, respectively, measured in a test specimen. The standard deviation of the Sr measurements (six test specimens) is indicated by the error bar attached to each date point. The standard deviation for the Co and Cs data were all less than the width of the symbols and are not shown.

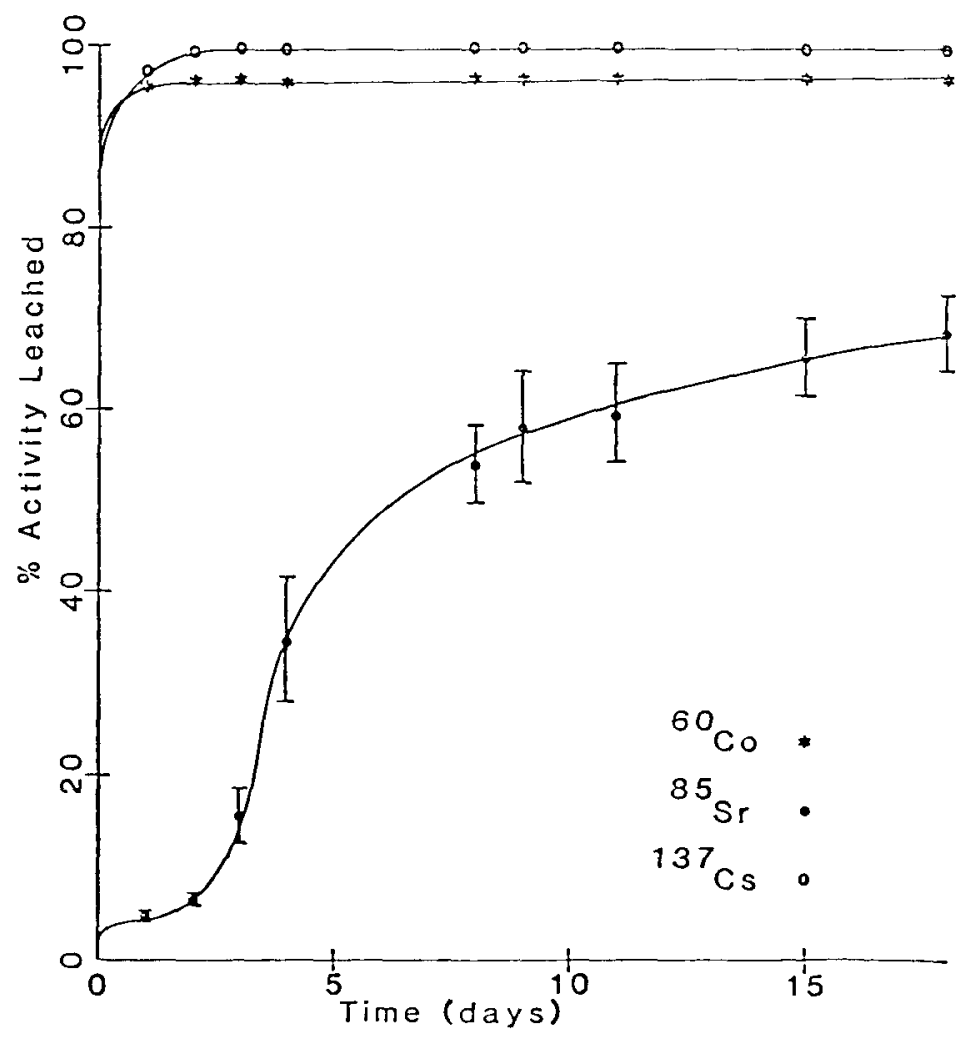

Figure 4.1 Percent activity loss vs time for Imperial 1146 strippable coating leached in deionized water. 
The data in Figure 4.1 indicate that $C s$ and Co leached readily from the coating upon contact with water. All of the Cs activity leached from the coating within four days with over $95 \%$ being released in the first leach volume. The behavior of Co paralleled that of Cs except that the coating retained about $4 \%$ of the initial Co activity. The behavior of $\mathrm{Sr}$ was more complex and varied considerably between test specimens, as indicated by the magnitudes of the error bars. About $5 \%$ of the Sr activity leached immediately. However, the curve shows that a longer period of contact with water was needed to release the major part of the Sr activity from the coating. About half of Sr activity was released readily and then the rate of release slowed markedly.

The radionuclide leaching of the coating measures the combined result of at least two effects: (1) the effect of the chelating agents in the coating and, (1i) the properties of the coating material itself. Chelating agents tend to solubilize metal lons and would be expected to enhance leachability whereas radionuclides more strongly bound to the coating material leach less readily. The relative quantity of chelating agent to radionuclide metal ion generally is very large and not a limiting factor.* One may speculate from Figure 4.1 that the $C s$ and most of the Co may be held in the set coating in the chelated form whereas most of the $\mathrm{Sr}$ may be bound preferentially to the coating.

\subsubsection{Chelate Leach Testing}

The ALARA 1146 strippable coating contains chelating agents the identities and quantities of which are considered confidential by Imperial.** According to the definition in 10 CFR Part 61.2, "Chelating Agent" means amine polycarboxylic acids (e.g., EDTA, DTPA), hydroxy-carboxylic acids, and polycarboxylic acids (e.g., citric acid, carbolic acid, and glucinic acid). $10 \mathrm{CFR} 20.311 \mathrm{~b}$ requires that radioactive waste containing more than $0.1 \%$ by weight of chelating agents be identified on the shipping manifest and that the weight percentage of chelates in this waste be estimated. As part of an agreement $(30)$ between Imperial Profession Coating Corporation and BNL, Imperial disclosed the identities and quantities of chelating agents in the ALARA 1146 composition to BNL. Based on this information from Imperial, BNL performed standard analyses for the chelating compounds in leachate samples from leaching ALARA 1146 coating in deionized water. The results from these tests on chelates leached from the coating were consistent with the quantities

\footnotetext{
* The quantities, in gram atoms (or moles) per $\mu \mathrm{Ci}$ of activity, of the radionuclide of concern are: $\mathrm{Cs}-137=8.4 \times 10^{-11}, \mathrm{Sr}-90=8.1 \times 10^{-11}$, Co-60 $=1.5 \times 10^{-11}$. Chelating agents generally have molecular weights in the range of about one hundred to several hundred. Assuming, for purposes of conservative calculation, a molecular weight of 1000 and a concentration of $0.1 \%$ by weight results in $1 \times 10^{-6}$ moles of chelate per gram of material. Therefore, for an activity loading on the order of $1 \mu \mathrm{Ci} / \mathrm{g}$ in our hypothetical example, there would be more than 10,000 chelate molecules for each radionuclide ion.

** Personal communication between $\mathrm{R}$. Taylor (Imperial) and R. Barletta (BNL), June 7, 1982 .
} 
of chelates which were indicated by Imperial to be present in the ALARA 1146 composition. As such, the concentration of chelating agents in the coating wastes does not require identification on the shipping manifest.

\subsubsection{Immersion Testing}

Immersion tests were conducted to determine changes which might be expected when strippable coatings are contacted with five liquids that are believed to bound the range of liquid compositions that may be found in a shallow land burial environment. These included a commercially prepared liquid scintillation counting (ISC) cocktail, toluene, xylene, delonized water, and deionized water saturated with xylene and toluene. The LSC cocktail forms a two-phase suspension with water so this mixture was not tested. The results for water and the water saturated with toluene and xylene are the more relevant to conditions expected in a burial environment.

One-inch square coating specimens were weighed and immersed in $50 \mathrm{~mL}$ of the liquids. Four samples were exposed to each liquid. Weight gain was measured as a function of time at $1,2,6,8,9,13,17$, and 34 days of immersion. Data were calculated as:

$$
\text { Weight Gain }(\%)=\frac{W_{1}-W_{0}}{W_{0}} \times 100
$$

where $W_{1}$ is the weight of the sample at time 1 and $W_{0}$ is the weight of the sample before immersion. These data are shown in Figures 4.2 and 4.3.

After 34 days of immersion, the samples were removed from the liquids to air dry in the laboratory. Samples were weighed after 1, 2, 3, 4, and 7 days and percent weight changes calculated with respect to the pre-immersion weights. These data are shown in the plots in Figures 4.4 and 4.5 . (The points at day zero in Figures 4.4 and 4.5 are the same as those at day 34 in Figures 4.2 and 4.3 , respectively.)

Dimensions of the initially $1-i n . x 1-i n$. samples were measured fo1lowing the immersion phase and again following the drying phase. The immersion liquids were also evaporated and the residues weighed. These data are listed in Table 4.1 along with computed values for the volume gain based on the observed weight gain and the density of the immersion liquid.

These data indicate that ALARA 1146 coating is affected by exposure to water and the organic liquids tested. The coating swells upon immersion and shrinks upon drying. A part of the coating dissolves upon immersion, as evidenced by the presence of a residue upon evaporation of the immersion 1iquid. For water and water saturated with toluene and xylene, the residue is a dry powder. For toluene and xylene the residue is a viscous oil. In water and the water solution saturated with toluene and xylene, the sum of the final weight (after drying) and the residue weight is less than the initial weight, as shown in Table 4.1, whereas for toluene and xylene, the final weight plus the residue weight is greater than the initial weight by approximately $10 \%$. This may suggest that toluene and xylene react with some constituent of the coating. 


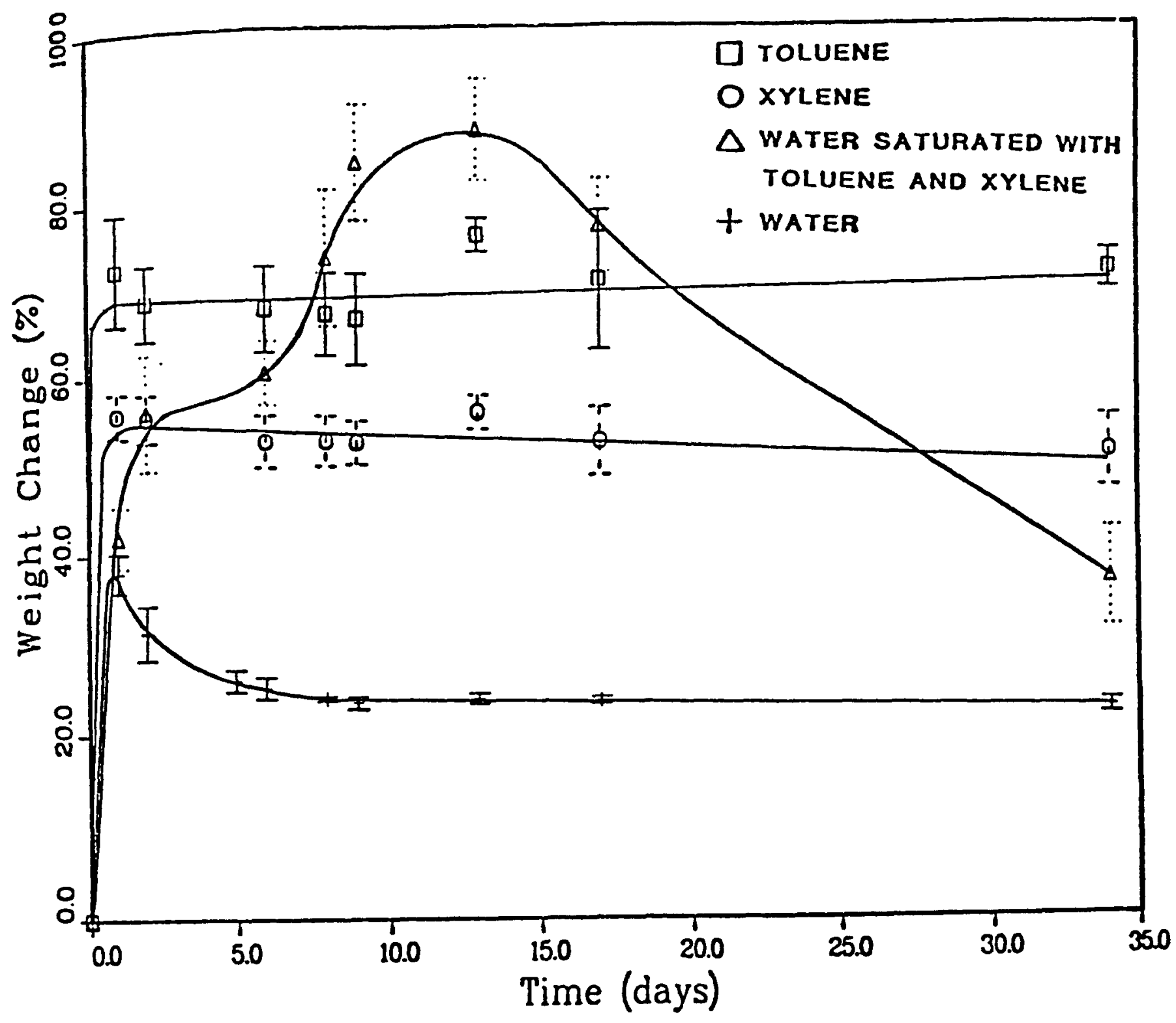

Figure 4.2 Percent weight gain of ALARA 1146 strippable coating upon immersion in toluene, xylene, water, and a solution of water saturated with toluene and xylene. 


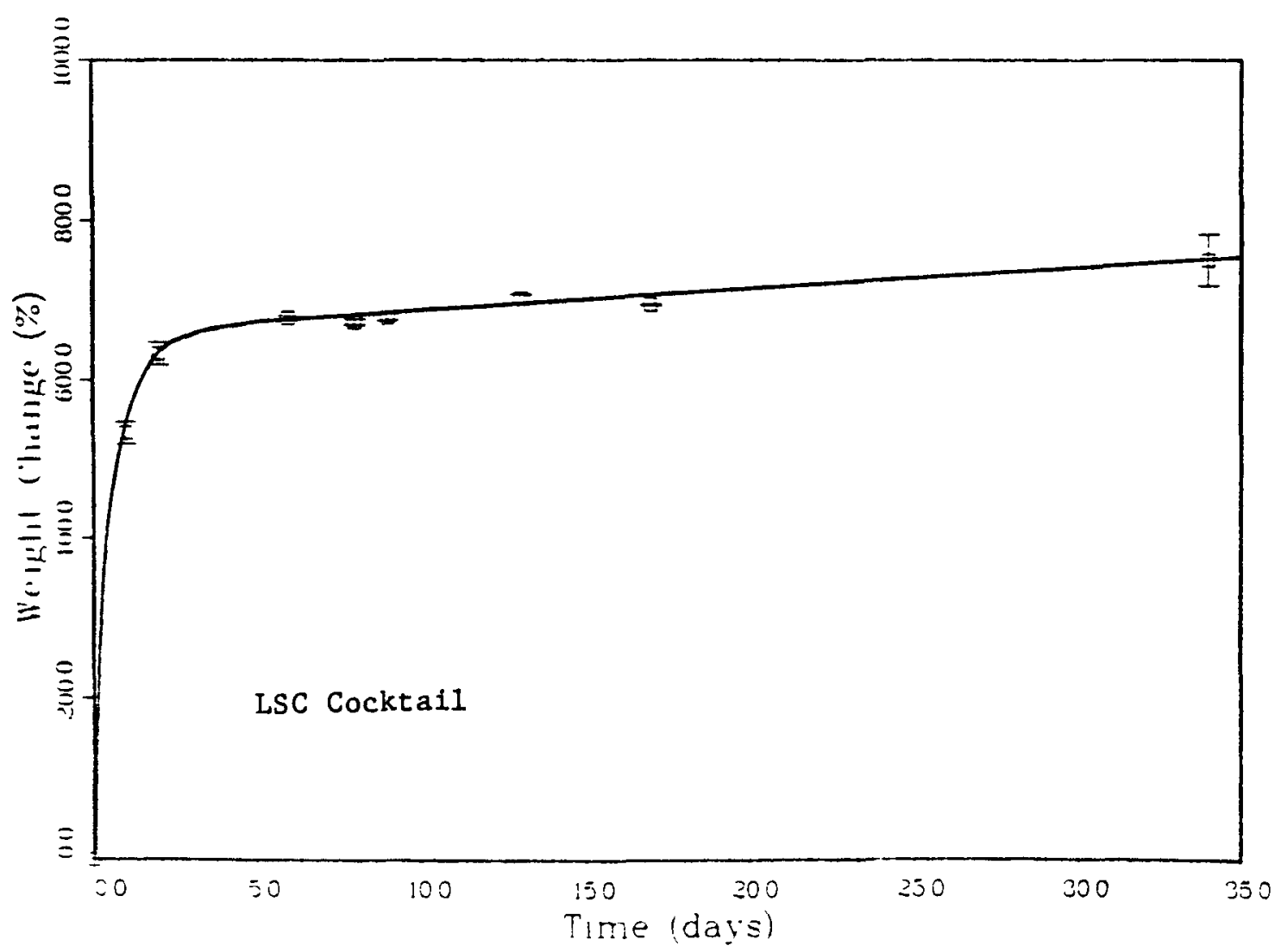

Figure 4.3 Weight gain of ALARA 1146 strippable coating upon immersion in LSC cocktail. 


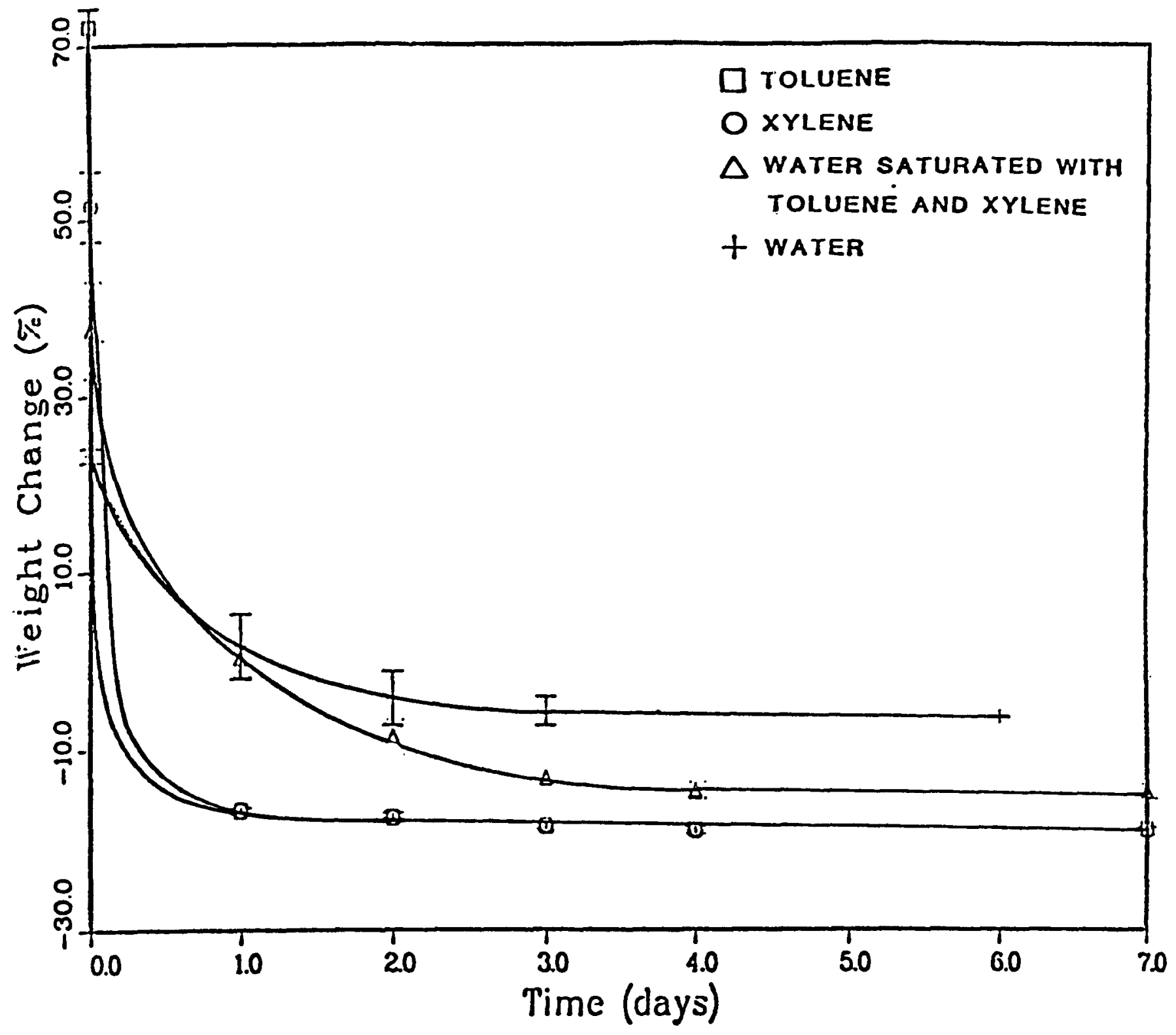

Figure 4.4 Drying curves at room temperature in air for ALARA 1146 stippable coating following 34 days immersion in toluene, xylene, water, and a water solution saturated with toluene and xylene. 


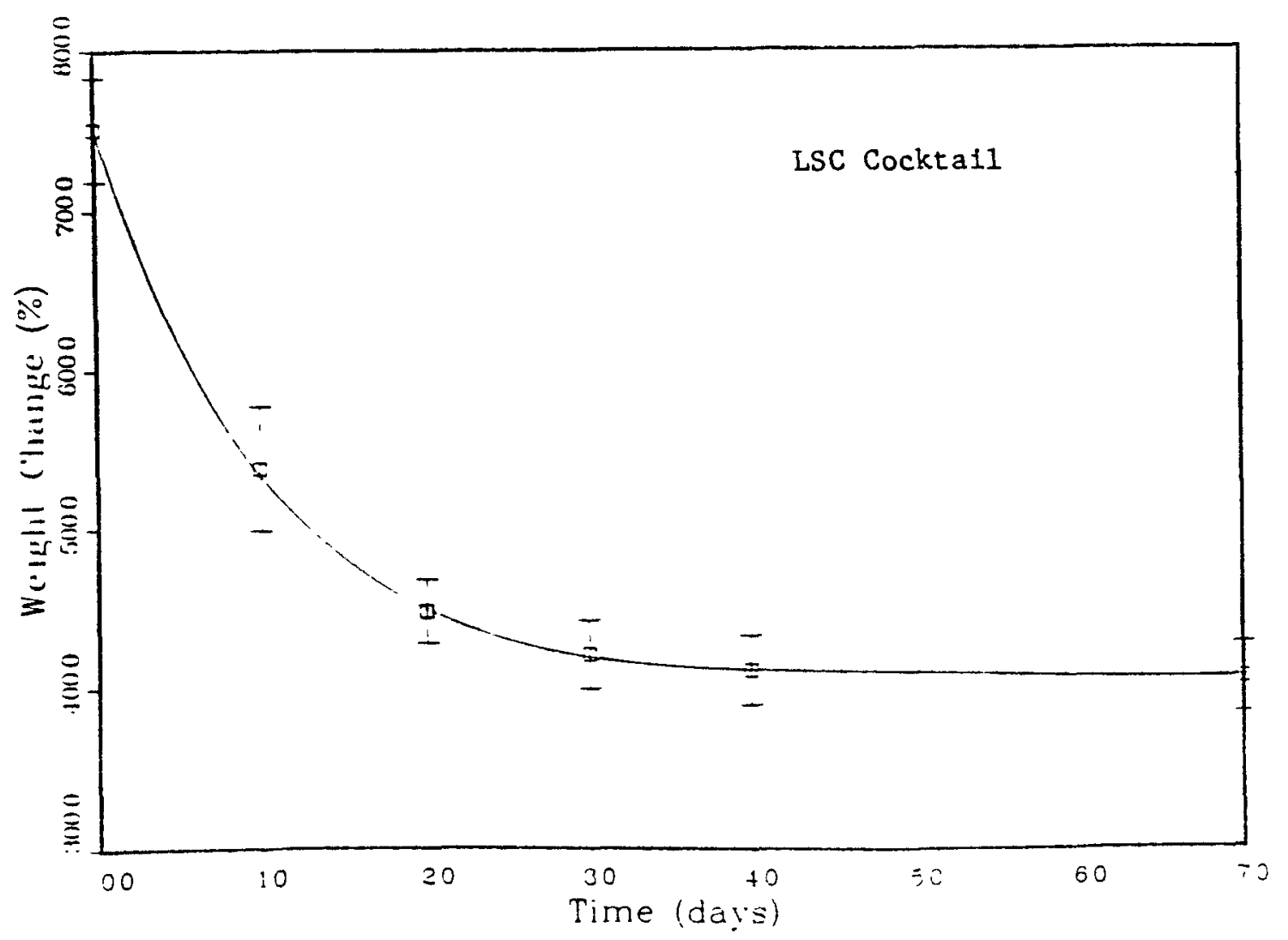

Figure 4.5 Drying curve at room temperature in air for ALARA 1146 strippable coating following 34 days immersion in LSC cocktail.

Tahle 4.1

Immeralon and Dryinp Dnt" for AlARA 1146 Strlppmble Cont Inp

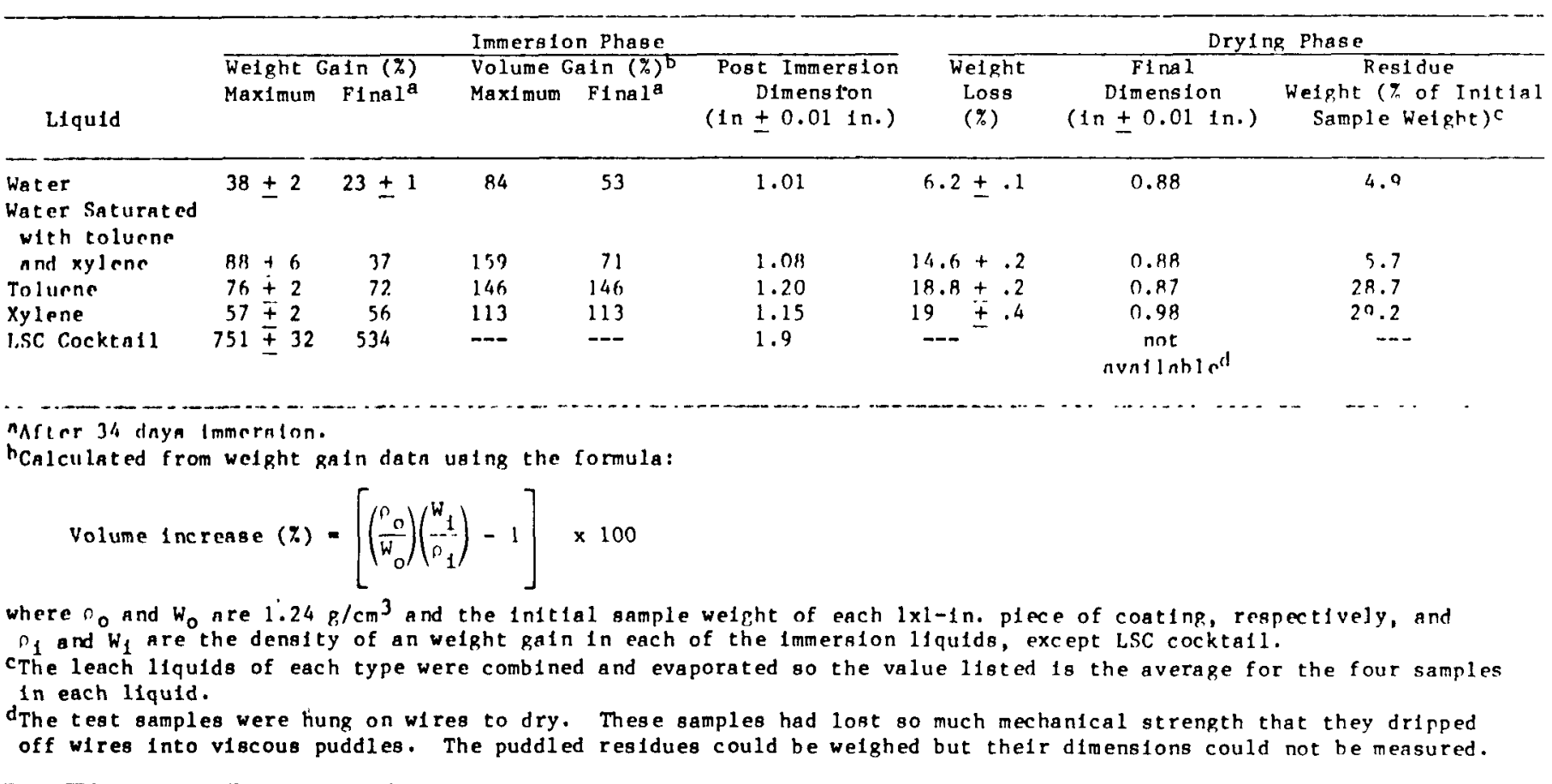




\subsubsection{Biodegradation Scoping Tests}

The biodegradability of ALARA 1146 strippable coating was determined two ways. The rate of blodegradation in soils from the Barnwell, SC, and Hanford, WA, shallow land burial sites was quantitatively monitored by measuring the $\mathrm{CO}_{2}$ produced from microblal respiration. Microbial $\mathrm{CO}_{2}$ production in soil was monitored using the special flasks and procedure described by Bartha and Pramer. (36) Biodegradation in soil(37-41) is controlled by the inherent biodegradability of the material plus related soll factors including moisture and nutrient mineral content, temperature and microbe types and population. In addition an evaluation of the ability of microbes to utilize the coating as a food source was performed using the ASTM tests G21 (Determining Resistance of Synthetic Polymeric Materials to Fung1) and G22 (Determining Resistance of Plastics to Bacteria). The Branch Technical Position on Waste Form (204.1.5/TCJ/1/5/83, February 14, 1983) specifies the use of G21 and G22 for testing resistance to biodegradation of waste forms which fall under 10 CFR Part 61 Class B or C. In G21 and G22, an ideal environment of moisture, temperature, and nutrient minerals is provided; these tests measure the inherent biodegradability (i.e., ability to be used as a food source) of a material to the microbes specified in the tests.

For biodegradation of Imperial 1146 strippable coating in soll, the 1146 coating was cut into strips approximately $1 / 2 \times 2$ inches. Fifteen to twenty of these strips with a total welght of approximately $12 \mathrm{~g}$ were used for each sample. Each of these samples was mixed in a speclal flask with $100 \mathrm{~g}$ moist soil (the moisture content was adjusted until the soil was wet but still porous and not muddy) from either the Barnwell or Hanford shallow land burial site. Two sample-in-soil tests were run for both of the burial site soils to provide an estimation of the reproducibility of the results. One sample plus $15 \mathrm{~mL}$ water was loaded into a flask without soil and two more flasks containing $100 \mathrm{~g}$ of the moist soll from the Barnwell and Hanford sites were used as controls. The difference between the $\mathrm{CO}_{2}$ produced in the flasks containing soil plus sample and the control containing soll only indicated sample biodegradation (more $\mathrm{CO}_{2}$ from sample flasks), inertness (no difference in $\mathrm{CO}_{2}$ production) or toxicity (decreased $\mathrm{CO}_{2}$ production). A standard potassium hydroxide $(\mathrm{KOH})$ solution, $0.100 \mathrm{M}$, was used to absorb any $\mathrm{CO}_{2}$ produced in a flask. When the $\mathrm{KOH}$ solution absorbed $\mathrm{CO}_{2}$, less acid was required for titration of the solution to the phenolphthalein indicator end point. To obtain the amount of $\mathrm{CO}_{2}$ generated, the $\mathrm{KOH}$ solution was removed from the flasks and titrated with $0.0500 \mathrm{M} \mathrm{HCl}$ solution. The amount of acid needed to titrate the remaining $\mathrm{KOH}$ is related to the $\mathrm{CO}_{2}$ absorbed by

$$
\mathrm{CO}_{2}(\mathrm{mg})=(\mathrm{B}-\mathrm{V}) \mathrm{NE}
$$

where $\mathrm{B}=\mathrm{mL} \mathrm{HCl}$ to titrate the soil control, $\mathrm{V}=\mathrm{mL} \mathrm{HCl}$ to titrate the sample in the soil, $\mathrm{N}=$ normality of the $\mathrm{HCl}$ and $\mathrm{E}=22$ (the equivalent weight of $\mathrm{CO}_{2}$ ). The time interval between titrations is determined by the rate of $\mathrm{CO}_{2}$ generation so as to not expend more than $2 / 3$ of the $\mathrm{KOH}$ in absorbing $\mathrm{CO}_{2}$. 
Results from the biodegradations in Barnwell soil, B1 and B2, and in Hanford soil, $\mathrm{H} 1$ and $\mathrm{H} 2$, are shown in Figure 4.6 and listed in Table 4.2 . Figure 4.6 shows the total quantity of $\mathrm{CO}_{2}$ generated by each of the four samples with time. Table 4.2 lists data for each including the quantity of $\mathrm{CO}_{2}$ generated and sample weights before and after the 220 days of biodegradation. The amount of biodegradation that has occurred is estimated from these data. Carbon dioxide generation monitored after the samples were removed from the soils indicated that microbial activity continued at a level significantly above that in the soil controls but was decreasing steadily with time.

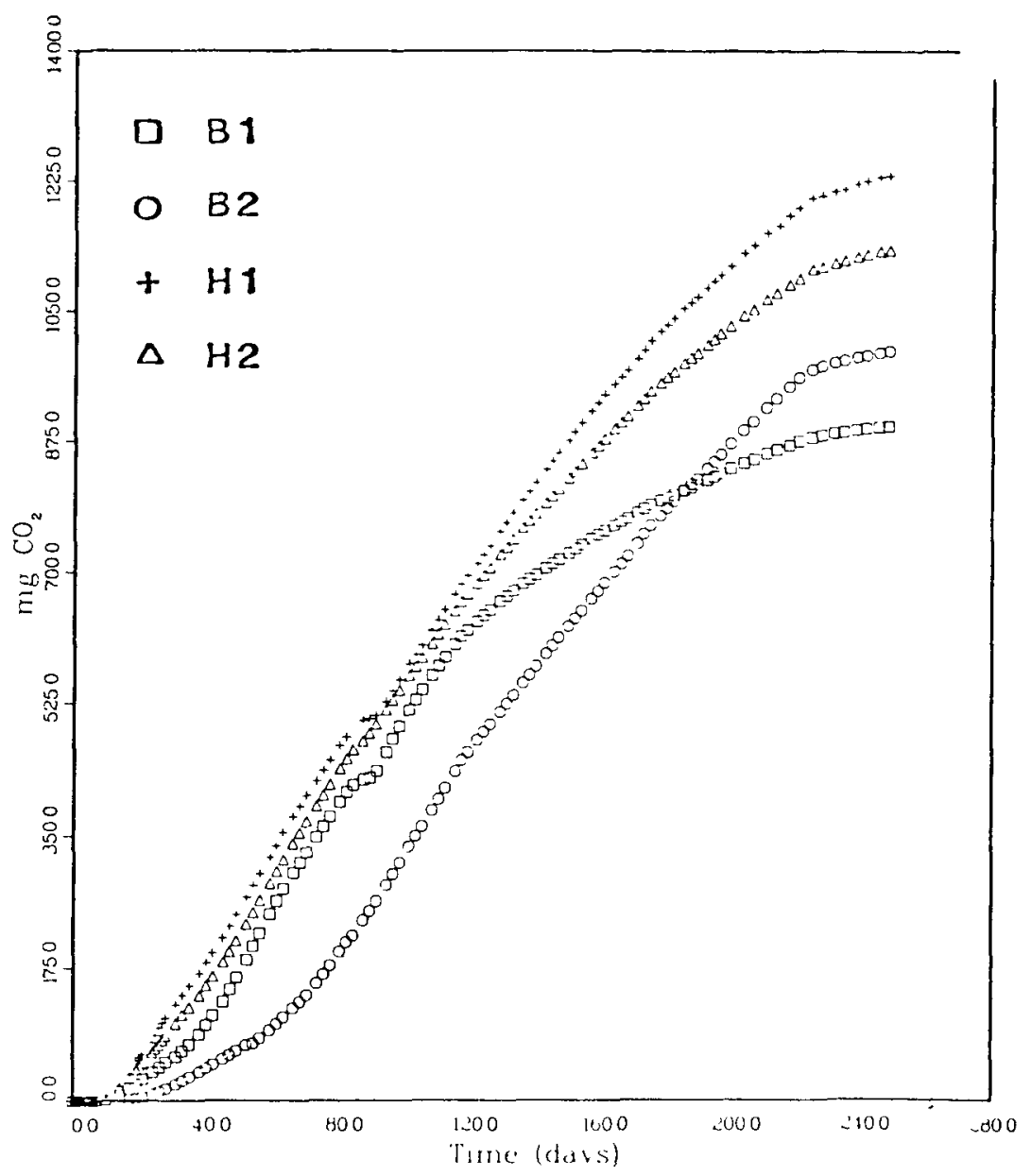

Figure 4.6 Biodegradative $\mathrm{CO}_{2}$ gas evolution from scoping tests on Imperial 1146 coating in Barnwell and Hanford soils. 
Table 4.2

Scoping Test Results on the Blodegradation of

ALARA 1146 Strippable Coating in Solls From

the Barnwe11, SC, and Hanford, WA, Shallow Land Burial Sites

\begin{tabular}{|c|c|c|c|c|c|c|}
\hline Sample & $\begin{array}{l}\text { Initial } \\
\text { Weight } \\
w_{0}(g)\end{array}$ & $\begin{array}{l}\quad \text { Final } \\
\text { Weight } \\
W_{f}(g)\end{array}$ & $\begin{array}{l}\text { Biogenically } \\
\text { Generated } \\
\mathrm{CO}_{2} \text { (mg) }\end{array}$ & $\frac{\mathrm{Carb}}{\% \mathrm{C}}$ & $\frac{\frac{\operatorname{Lost}^{a}}{\% C^{b}}}{0.6}$ & $\frac{W_{\Omega}-W_{f}}{W_{O}} \times 100^{c}$ \\
\hline $\begin{array}{c}\text { B1 } \\
\text { B2 } \\
\text { H1 } \\
\text { H2 } \\
\text { Contro1 }\end{array}$ & $\begin{array}{l}12.11 \\
11.97 \\
11.24 \\
11.24 \\
11.74\end{array}$ & $\begin{array}{l}11.25 \\
11.05 \\
10.31 \\
10.48 \\
12.18\end{array}$ & $\begin{array}{r}875.5 \\
961.0 \\
1094.5 \\
1189.5 \\
\text { n11 }\end{array}$ & $\begin{array}{l}3.77 \\
4.19 \\
5.08 \\
5.52 \\
- \\
---\end{array}$ & $\begin{array}{l}6.28 \\
6.98 \\
8.47 \\
9.20 \\
-\end{array}$ & $\begin{array}{c}7.10 \\
7.69 \\
8.27 \\
6.76 \\
-3.75 \mathrm{~d}\end{array}$ \\
\hline
\end{tabular}

a From the biogenically generated $\mathrm{CO}_{2}$ data and the measured $52.3 \% \mathrm{C}$ content of the coating used in these tests.

bThis is the estimated upper limit of biodegradation based on this $\mathrm{CO}_{2}$ generation data and published observations, References 39 and 40 , that as Iittle as $60 \%$ of the available carbon may be evolved as $\mathrm{CO}_{2}$ during biodegradation.

cPercent biodegradation from the initial and final weight following 220 days of biodegradation in soil at $20-24^{\circ} \mathrm{C}$.

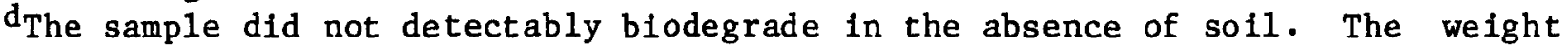
increase should not be due to retained water since all samples were dried both infore and after the tests in the same enviroment.

Carbon dioxide monitoring provides a lower limit to the amount of blodegradation that has occurred. This is so for two reasons. First, as little as $60 \%$ of the biodegradable carbon in a substrate may be evolved as $\mathrm{CO}_{2} ;(39,40)$ the remainder is incorporated into additional microbe mass or excreted as metabolic waste other than $\mathrm{CO}_{2}$. Second, only carbon metabolism is measured by this technique; thus, neither the metabolism of hydrogen and oxygen to produce water nor other transformations (e.g., sulfate or nitrate metabolism) which may occur in the substrate are accounted for in this method. However, $\mathrm{CO}_{2}$ monitoring does provide a quantitative measure of biodegradation and allows measurement of changes in the rate of biodegradation with time.

Comparison of initial and final sample weights should be a direct measure of the amount of biodegradation that has occurred. Difficulties in separating tightly bonded soil from the coating, the loss of very small amounts of coating with the soil removed from the coating surface and contributions from microbe mass retained on the coating complicated the interpretation of this data. The weight added by retained soil and microbe mass is 
offset to some degree by coating removed with soil. A greater quantity of soil was incorporated into the coating than coating was scraped off with the soil (with the probable exception of $B 2$ which is the only sample for which the biodegradation measured by weight change did not lie within the range of probable biodegradation as determined by carbon dioxide monitoring). These factors considered together led us to conclude that the final weights of the samples in soil (i.e., B1, B2, H1 and H2) may be each slightly high, perhaps by as much as, but certainly not more than, a few tenths of a gram.

There are several prominent features in Figure 4.6. Two of these features, the 10-day initial part of the curves with very low rates of $\mathrm{CO}_{2}$ generation and the "kinks" in the curves from day 84 to approximately day 94 , resulted from unplanned occurrences during the tests. The initial region of each of the curves is characterized by a low rate of $\mathrm{CO}_{2}$ evolution followed by the onset, at day 10, of much higher rates of biodegradation. This was probably caused by cold temperatures (45-570 F daytime, colder at night) due to fallure of a steam valve which supplied heat to the lab. From day 10 on, lab temperature was maintained between 68 and $74^{\circ} \mathrm{F}$. The region of reduced $\mathrm{CO}_{2}$ evolution, which is especially noticeable in samples $\mathrm{B} 1$ and $\mathrm{H} 1$, from day 84 to about day 94 was caused by an accident on day 84 in which some aikaline solution was spilled into some or all of the samples. The microbes recovered from this trauma and the rates of $\mathrm{CO}_{2}$ generation returned to pre-accident levels within 10 days.

A difference in the way the coating samples were mixed with the soils is probably the cause of relative difference in the B1, B2 and $H 1, H 2$ curves. Sample BI was mixed with soil such that it had approximately $50 \%$ more surface area in direct soil contact. Specifically, there was less overlapping of coating strips in $\mathrm{B} 1$ than in $\mathrm{B} 2, \mathrm{H} 1$, and $\mathrm{H} 2$. $\mathrm{B} 1$ initially biodegrades significantly faster than $B 2$ whereas, the rates for $\mathrm{H} 1$ and $\mathrm{H} 2$ were very similar to each other. It appears that biodegradation of this material proceeds faster in Hanford soil, all other things being equal. The rates of $\mathrm{CO}_{2}$ generation from all four samples are essentially. equal from about day 80 to 120 , at which point the rate of $\mathrm{CO}_{2}$ generation in $\mathrm{Bl}$ slows significantly. The reason for this slowing is not clear. It should not have been caused by the accident at day 84 since there was a complete recovery in $\mathrm{CO}_{2}$ generation and no similar slowing occurred in $H 1$ which was also severely affected by the accident. Although $\mathrm{CO}_{2}$ generation from all of the samples was gradually slowing, this effect in $B 1$ was much more pronounced.

The samples were removed from the soils on day 220 of the experiment. $\mathrm{CO}_{2}$ production from these soils minus samples decreased significantly but did not return to background. This may be due to the small quantities of coating adhering to the soil in direct contact with the samples and possibly due to a soluble fraction of the coating, as is indicated by the immersion testing (Section 4.1.4), remaining with the soil. The rate of $\mathrm{CO}_{2}$ generation in the soils after sample removal gradually decreased toward background with time. 
The ASTM tests G21 and G22 were run on coating samples approximately $1 \times 1 \mathrm{in}$. in size. G21 (fung1) showed no growth, i.e., a growth rating of zero on a scale of $0-4$ in the test. 622 (bacteria) was positive for bacterial growth on the coating specimen. (There is no quantiative scale in G22, results are reported as growth or as no growth.)

\subsubsection{Radiation Testing}

The stability of ALARA 1146 strippable coating to fonizing radiation was tested using coating specimens sealed into Pyrex tubes both in an air atmosphere and under vacuum. Gamma irradiation was carried out in the Co-60 irradiation facility at BNL. Data included pressure measurements for the tubes both before and after irradiation and mass spectroscopic analysis of the gas in the tubes after irradiation. The coating generated gas when exposed to ionizing radiation, as was expected, since chemically, it is an organic substrate. $(42,43)$ It also was changed physically by the irradiation, becoming much stiffer and stronger with increasing dose. This change could also be anticipated since the polymeric coating would be expected to cross-iink upon exposure to lonfzing radiation. $(43,43)$

The measured data from the sealed tube irradiations in air and vacuum are shown in Figure 4.7. Three experimental configurations, as differentiated by the symbols, were used in the $20 \mathrm{~cm}^{3}$ sealed tubes: squares $-0.5-g$ coating in air; triangles - $5.0 \mathrm{~g}$ coating in air, and circles - 5.0-g coating in vacuum. The vertical bars through the center of each symbol represent the standard deviation of the four measurements at each data point. The $0.5-g$ sample irradiations were performed first to guide the selection of points for further study. A preliminary gas analysis indicated that the negative slope of the line defined by the square data points up to about $10^{8}$ rad was caused by oxygen depletion. At doses greater than $10^{8}$ rad, radiolytic gas generation became dominant. The line defined by the square data points at $5 \times$ $10^{8} \mathrm{rad}$ and $1 \times 10^{9}$ rad indicate a $G$ value for gas generation of 1.3 .

The quantity of gas generated per gram of coating was less in the sealed tubes containing $5.0 \mathrm{~g}$ of coating than in the preliminary tests using $0.5 \mathrm{~g}$ coating. This is probably due to the higher pressures, as 1 isted in Table 4.3, produced in tubes with the larger amount of coating. The higher pressures would increase the extent of back reaction (i.e., the coating would react with the radiolysis gas and reduce the net amount of gas produced) and a lower apparent $G$ value. The pressure in the tubes containing $0.5 \mathrm{~g}$ of sample Irradiated to $1 \times 10^{9} \mathrm{rad}$ was slightly less than $2 \mathrm{~atm}$.

Table 4.3 lists the gas generation data for doses of $10^{8} \mathrm{rad}$ and greater, for the points indicated by circles and triangles in Figure 4.8 , 1.e., for the 5.0-g samples irradiated in air and under vacuum. The pressure in these tubes at the end of the irradiation is also 1isted. For reference, the composition of dry normal air at sea level and a gas analysts for an unirradiated $5.0 \mathrm{~g}$ sample sealed from air are also listed. The sensitivity of the gas analysis is in the range of $0.05 \%$ by volume for detection. The data show that oxygen is scavenged from air over the samples and that hydrogen is the 
primary radiolysis product being generated. Carbon dioxide, hydrocarbons including methane, ethane, propane, butane plus others and a small amount of carbon monoxide account for the remainder of the gas produced by radiolysis of the coating. Radiolytic gas generation causes also the coating to blister, as shown in Figure 4.8 for a plece of coating 1 rradiated to $1 \times 10^{9} \mathrm{rad}$.

The gas analysis of the sample which was sealed in a tube but not irradiated was surprising - the coating appears to scavenge oxygen and liberate carbon dioxide, carbon monoxide, and a small amount of hydrogen spontaneously at room temperature. The unirradiated sample remained sealed for 7 weeks prior to analysis. It seems unlikely that biodegradation could be responsible for the oxygen uptake and $\mathrm{CO}_{2}$ generation in the sealed tube based on the $\mathrm{CO}_{2}$ monitoring results of Section 4.1 .5 on the molstened coating not in soil. Also, there was no moisture in the sealed tube to support biodegradation, and carbon monoxide, which was produced in the sealed tube, is a product of decomposition, not biodegradation.

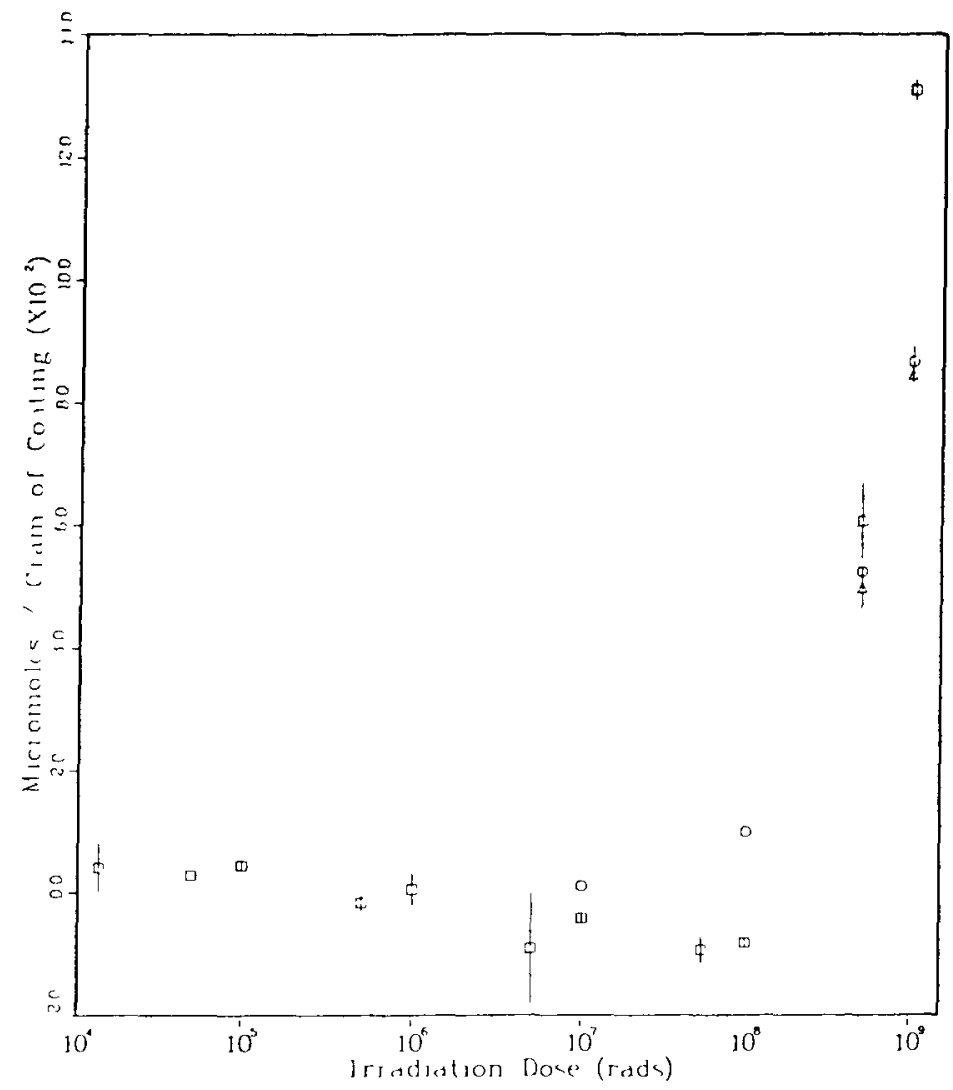

Figure 4.7 Plot of gas generation vs Co-60 gamma dose for ALARA 1146 strippable coating. Three sample configurations were used in $20 \mathrm{~cm}^{3}$ sealed tubes: squares - 0.5-g coating in air; trianges - 5.0-g coating in air and; circles - 5.0-g coating in vacuum. 
Table 4.3

Gas Composition Analysis From Co-60 Gamma Irradiated Tests of ALARA 1146 Strippable Coating in A1r and Under Vacuum ${ }^{8}$

\begin{tabular}{|c|c|c|c|c|c|c|c|c|c|c|c|c|c|c|}
\hline \multirow{2}{*}{$\begin{array}{l}\text { Irradiation } \\
\text { Dose } \\
\text { (rad) }\end{array}$} & \multirow[b]{2}{*}{$\begin{array}{c}\text { Inttial } \\
\text { Environment }\end{array}$} & \multirow[b]{2}{*}{$\begin{array}{l}\text { Pressure } \\
\text { (atm) }\end{array}$} & \multicolumn{12}{|c|}{ Gas ( $z$ by Volume) } \\
\hline & & & $\mathrm{N}_{2}$ & $\mathrm{o}_{2}$ & Ar & $\mathrm{CO}_{2}$ & $\mathrm{H}_{2}$ & co & $\mathrm{CH}_{4}$ & $\mathrm{C}_{2} \mathrm{H}_{6}$ & $\mathrm{C}_{3} \mathrm{H}_{8}$ & $\mathrm{C}_{4} \mathrm{H}_{10}$ & $\begin{array}{c}\text { Other } \\
\text { Hydrocarbons }\end{array}$ & $\bar{z}$ \\
\hline $0^{b}$ & -- & 1.0 & 78.1 & 20.9 & 0.93 & 0.034 & & & & & & & & 99.964 \\
\hline$u^{c}$ & alr & 0.9 & 72.5 & 11.8 & 0.90 & 10.8 & 0.25 & 3.7 & & & & & & 99.95 \\
\hline $5 \times 10^{8}$ & dir & 4.8 & 13.3 & & & 12.6 & 65.4 & 2.0 & 2.1 & 0.7 & 2.2 & 1.1 & 0.6 & 100.0 \\
\hline $1 \times 10^{9}$ & $a 1 r$ & 7.3 & 6.6 & 0.2 & & 14.8 & 70.3 & 1.8 & 2.3 & 1.0 & 1.8 & 0.8 & 0.5 & 100.1 \\
\hline $1 \times 10^{8}$ & vacuum & 0.7 & & 0.09 & & 12.3 & 76.8 & 2.0 & 1.9 & 0.6 & 2.5 & 2.7 & 1.2 & 100.09 \\
\hline $1 \times 10^{8}$ & vacuum & 4.0 & & 0.4 & & 11.7 & 78.3 & 2.0 & 2.1 & 0.9 & 2.3 & 1.7 & 0.4 & 99.8 \\
\hline $5 \times 10^{8}$ & vacuum & 6.7 & & 0.2 & & 15.0 & 75.1 & 2.6 & 2.6 & 1.1 & 2.0 & 1.0 & 0.5 & 100.1 \\
\hline 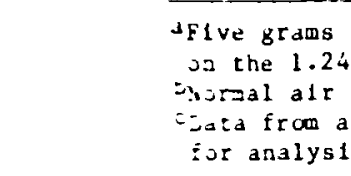 & $\begin{array}{l}\text { of ALARA } 1146 \\
\mathrm{~g} / \mathrm{cm}^{3} \text { densit } \\
\text { dt sea level } \\
\text { sample tube } \\
\text { s } 7 \text { weeks lat }\end{array}$ & $\begin{array}{l}\text { coating we } \\
\text { of the co } \\
\text { exclusive o } \\
\text { that was no } \\
\text { er, when al }\end{array}$ & $\begin{array}{l}\text { re } 1 \text { rr } \\
\text { ating } \\
\text { f wate } \\
\text { t irra } \\
\text { l of } t\end{array}$ & $\begin{array}{l}\text { lated } 1 \\
\text { can be } \\
\text { vapor. } \\
\text { ated. } \\
\text { analyg }\end{array}$ & $\begin{array}{l}\text { n seal } \\
\text { deter } \\
\text { It was } \\
\text { es wer }\end{array}$ & $\begin{array}{l}\text { d tubes } \\
\text { ined } f r \\
\text { sealed } \\
\text { perfor }\end{array}$ & $\begin{array}{l}\text { with a } \\
\text { speci } \\
\text { at the } \\
\text { aed. }\end{array}$ & $\begin{array}{l}\text { tal v } \\
\text { catio } \\
\text { te tin }\end{array}$ & $\begin{array}{l}\text { ume } \\
\text { In } \\
\text { as th }\end{array}$ & $\begin{array}{l}20 \mathrm{~cm}^{3} \\
\text { ALARA } \\
\text { Cubes }\end{array}$ & $\begin{array}{l}\text { The ple } \\
46 \text { Tech } \\
\text { irrad } 1\end{array}$ & $\begin{array}{l}\text { cal volum } \\
\text { can and }\end{array}$ & $\begin{array}{l}1 \mathrm{~s} 16 \mathrm{~cm}^{3} \mathrm{ba} \\
\text { sheet, Appen } \\
\text { the seal was }\end{array}$ & d \\
\hline
\end{tabular}




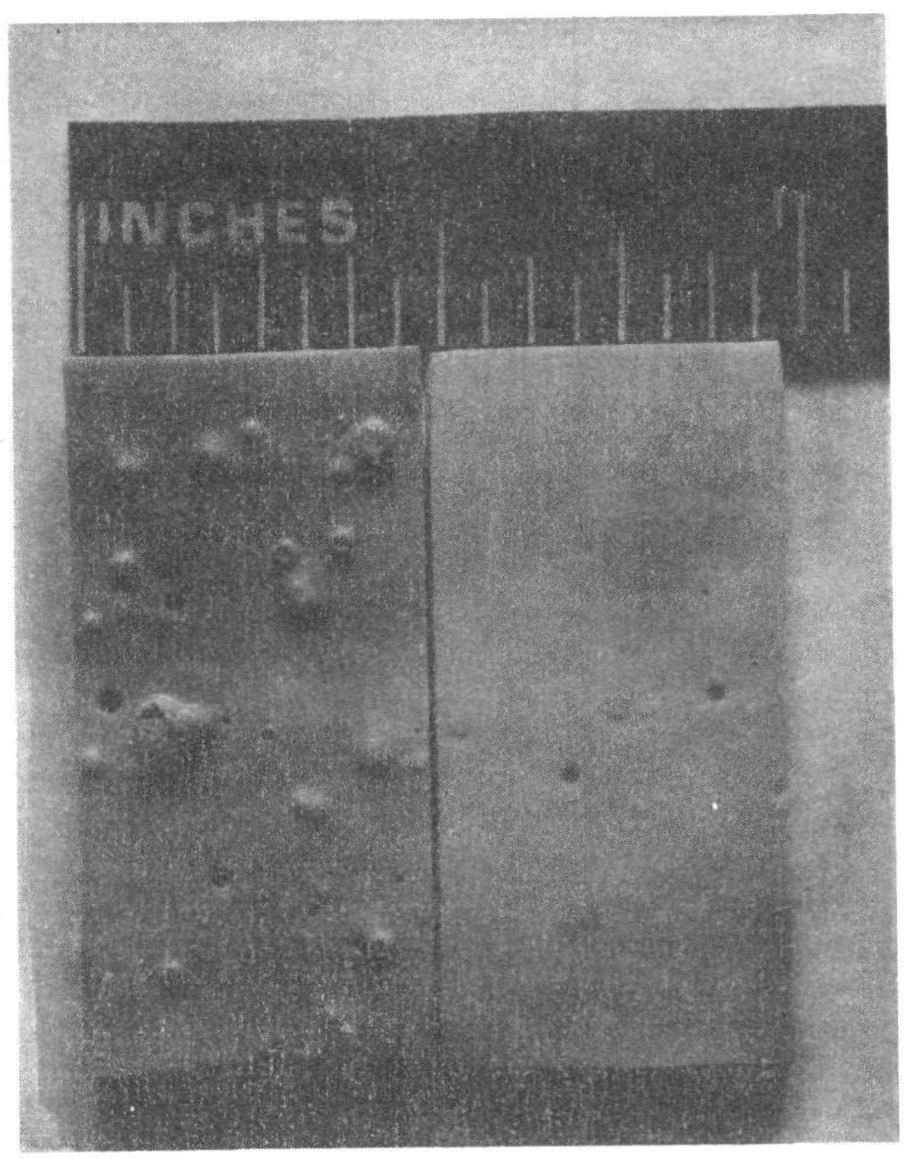

Figure 4.8 Effect of radiolysis on ALARA 1146 coating (left) vs unirradiated specimen ( $r i g h t$ ).

\subsubsection{Thermal Testing}

The thermal resistance of ALARA 1146 strippable coating has been tested according to ASTM E84-77 (Surface Burning Characteristics of Building Materials).(44) This test was performed to document the compliance of the 1146 coating to NRC Draft Regulatory Guide 1.120, "Fire Protection Guidelines for Nuclear Power Plants" (Revision 1, November 1977). ASTM E-84 compares the burning characteristics of a test material to those of asbestos cement board, which is nonflammable, and to red oak wood paneling. Test results are stated numerically on a scale of 0-100 in which the asbestos cement board results define zero and the red oak wood paneling results define 100 on the scale. A 20-25 mil thickness of the 1146 coating had a flame spread rating of 20 and a 30-35 mil thickness was rated at 40. The NRC Draft Regulatory Guide 1.120 limits the flame spread behavior to a value of 50 for use in nuclear plants.

To determine the effect of heat on the coating, without burning, $1 \mathrm{x}$ 1 in. pieces of coating were sealed into glass tubes at atmospheric pressure and then heated for $24 \mathrm{~h}$ at 50,100 and $200^{\circ} \mathrm{C}$. there were no visible changes 
In the coating samples heated to 50 and $100^{\circ} \mathrm{C}$ whereas the $200^{\circ} \mathrm{C}$ sample became darker in color. Table 4.4 lists the results of gas analyses on the atmospheres in the tubes. The final pressure in all of the tubes was reduced to a small fraction of the inftial pressure of approximately $0.9 \mathrm{~atm}$, which is normal for this procedure.* The disappearance of most of the oxygen from the air over the samples provides additional evidence that the 1146 coating scavenges oxygen from air. Specifically, it was previously observed (c.f. Iine 2, Table 4.3) that oxygen was disappearing from the air over a piece of 1146 coating in a sealed tube at room temperature. Ralsing the temperature, as has been done in the thermal tests, would be expected to increase the rate of reaction. Likewise, the generation of carbon dioxide, hydrogen, and carbon monoxide was anticipated plus some pyrolysis at higher temperatures to produce various organic decomposition products. The absence of the nitrogen and argon, as indicated by the low final pressure, as well as the gas analysis was surprising since these gases are inert under the thermal testing conditions used (argon is chemically inert under all conditions). A possible explanation may be that some of the organics generated by thermal decomposition have significant vapor pressure at elevated temperatures but not at room temperature coupled with a leakage of gas from the tube at elevated temperatures and high internal pressures. One could then also expect condensate in the sealed tube after cooling. Although none was observed, no effort was made to determine the possible presence of condensate at the time of the experiment and a colorless, transparent film could have escaped observation. The explanation for the low final pressures in the tubes following the thermal tests is based only on speculation and these results should remain suspect until independently verified by additional experiments.

\footnotetext{
* The heat from sealing the break-seal tubes used in these procedures, as well as in the irradiation tests, normally reduces the pressure in the sealed tubes to approximately $90 \%$ of ambient pressure.
} 
Table 4.4

Gas Analysis From the Thermal Testing of ALARA 1146 Strippable Coatinga

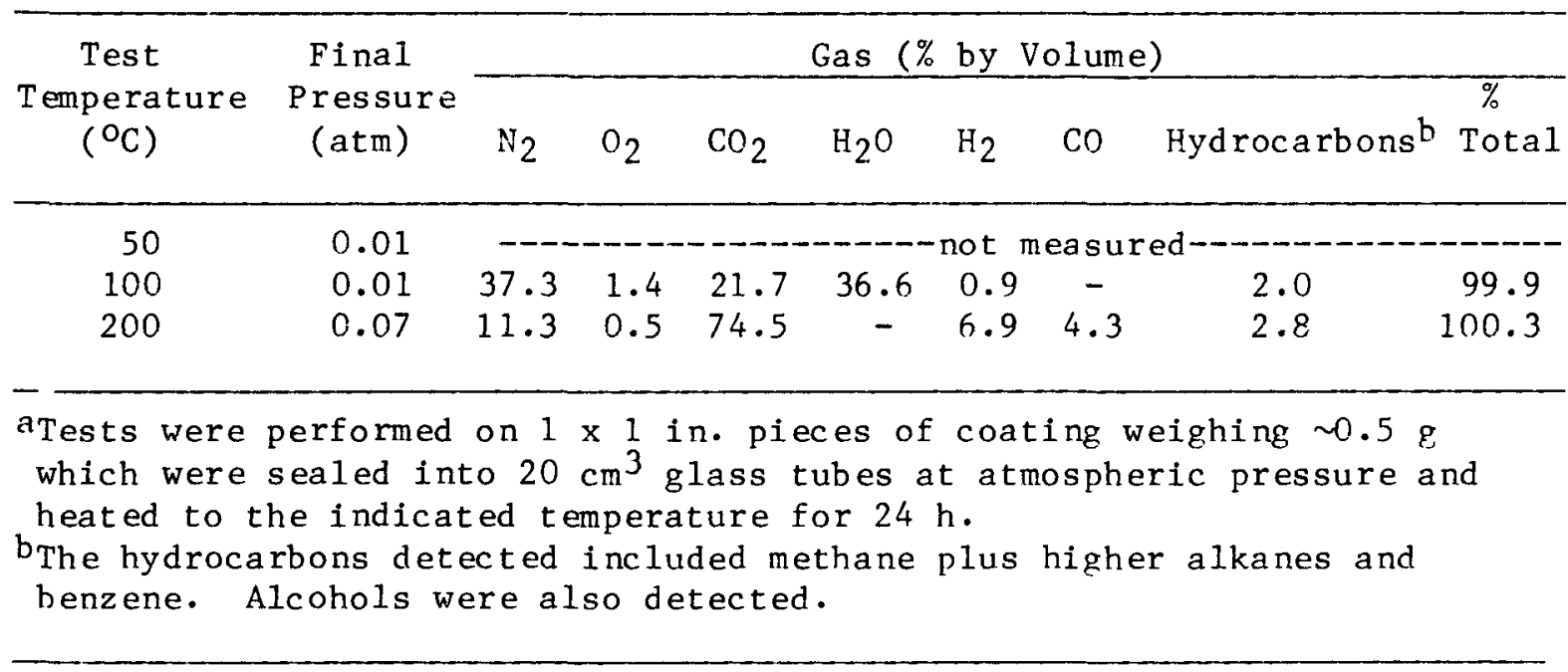

\subsubsection{Scoping Tests Summary}

The results of the scoping tests on ALARA 1146 strippable coating, as presented in Sections 4.1 .2 through 4.1.7, are summarized below.

- Radionuclide leach testing in deionized water showed that Cs leaches readily and completely from the coating; Co leaches readily except for a small amount retained by the coating while Sr leaches from the coating much more slowly and with large variations in leach rate between different coating pieces.

- Chelate leach testing indicated that the chelating agents contained in the 1146 coating leach in deionized water. However, the quantity of chelating agent contained in the coating is less than $0.1 \%$ by weight.

- Immersion testing showed that the 1146 coating is attacked by water and the several organic liquids tested. It absorbed liquid, as indicated by weight gain and swelling during immersion. Additionally, part of the coating dissolved as indicated by weight loss upon drying and residues remaining upon evaporation of the immersion liquids. 
- Biodegradation tests showed that the coating biodegrades readily in moist soil. It appeared to biodegrade faster in Hanford soll than in Barnwell soll. The amount of biodegradation measured by monitoring $\mathrm{CO}_{2}$ produced from microbial respiration was confirmed by weight loss measurements on the biodegraded coating samples. The biodegradation is probably caused by bacteria and not fungi as indicated by the results of ASTM tests G21 and G22.

- Radiation stability testing showed that the coating generates yas, primarily hydrogen with lesser amounts of carbon dioxide, hydrocarbons, and carbon monoxide, with a G-value for total gas of approximately 1.3. It also consumes oxygen. Radiation improves the physical characteristics of strength and toughness of the coating and may enhance the resistance to chemical and biodegradative attack. In sum, the 1146 coating showed no meaningful radiation damage, except for gas generation, to doses of $10^{9} \mathrm{rad}$. Gas generation becomes significant (i.e., the volume of gas generated is approximately equal to the coating volume) above $10^{8}$ $\mathrm{rad}$.

- Thermal stability testing showed that ALARA 1146 is only moderately flammable and is not greatly affected by heat up to $100^{\circ} \mathrm{C}$ for short periods of time. It scavanges oxygen from the air even at room temperature. Some pyrolysis, as indicated by the generation of hydrocarbons, occurs at temperatures as low as $100^{\circ} \mathrm{C}$.

\subsubsection{Testing the Strippable Coating From TMI-2}

\subsubsection{TMI-2 Coating Samples}

Samples of strippable coating from the reactor building Gross Decontamination Experiment were sent to BNL for characterization. The TMI coating samples obtained consisted of five pieces individually packaged in numbered plastic bags. A summary of data on the coating pieces received from TMI including the bag number, weight, dimensions, and a gamma-activity measurement at approximately $5 \mathrm{~cm}$ is listed in Table 4.5 .

The large differences in the measured gamma activities listed in Table 4.5 agree with previous observations $(1,8)$ that the contamination in the reactor building is distributed inhomogeneously. There were no obvious differences between coating specimens from different bags, such as differing amounts of debris incorporated into coating samples with grossly differing activities. In fact, since the surface to which the ALARA 1146 coating was applied had been flushed with water prior to application, very little debris was observed on any of the coating pieces. Due to the inhomogeniety of the activities on the different coating pieces, there is no way of knowing whether this batch is representative of the average activity for the strippable coating radwaste produced in the Gross Decontamination Experiment or whether it may provide an estimate for expected activities on strippable coating radwaste which may be produced in decontaminating other parts of the reactor building. 
Table 4.5

Strippable Coating Samples from the TMI-2 Reactor Building Gross Decontamination Testing

(The bag numbers were on the plastic bags containing the individual coating samples as received)

\begin{tabular}{ccccc}
\hline $\begin{array}{c}\text { Bag } \\
\text { No. }\end{array}$ & $\begin{array}{c}\text { Sample } \\
\text { Weight }(\mathrm{g})\end{array}$ & $\begin{array}{c}\text { Sample } \\
\text { Width }(\mathrm{cm})\end{array}$ & $\begin{array}{c}\text { Sample } \\
\text { Length }(\mathrm{cm})\end{array}$ & $\begin{array}{c}\text { Activity at 5 cm } \\
(\mathrm{mrem} / \mathrm{h})\end{array}$ \\
\hline 50 & 7.77 & 9.0 & 17.5 & 3.5 \\
51 & 6.95 & 9.0 & 19.0 & 230 \\
52 & 4.50 & 9.8 & 15.2 & 150 \\
162 & 5.94 & 8.5 & 16.5 & 4.0 \\
163 & 4.13 & 8.5 & 11.5 & \\
Tota1 & $\mathbf{2 9 . 2 9}$ & & & \\
\hline
\end{tabular}

The TMI coatings were tested for radionuclide leaching and for biodegradation. The radionuclide leach tests, in which Cs-134,137 were monitored, were performed to compare results from these decontamination coatings in which the contamination was removed from a surface with the scoping test results in which the radionuclides were added to the liquid coating in an aqueous spike. Following this leach testing, the leachate and the leached coating specimen were sent to a commercial analysis laboratory (EAL Corporation*) for analysis for $\mathrm{Sr}$ and Pu content. Biodegradation tests in soil were run on these coatings to clarify the differences in biodegradation that were suggested by the scoping biodegradation tests.

\subsubsection{Leach Testing and Radionuclide Analysis on TMI-2 Coating}

The TMI coating sample from bag 162 (Table 4.5) was leached in deionized water for 43 days and then the leachate and the leached coating residue were sent to EAL Corp., a commerctal analysis laboratory, for further radionuclide analysis. Figure 4.9 shows the time intervals at which the leachate was changed and the cumulative $\mathrm{Cs}-137,134$ activity leached from the sample. Each leachate volume was counted for activity in a gamma spectrometer. The activity was quantifled using identical volumes with known activities of the specific radionuclides in aqueous solution. No gamma emitters other than Cs-134,137 and the Ba-137m daughter were unambiguously detected in the leachate. No Cs remained in leached coating sample and no other gamma emitters we re unambiguously detected in the leached coating sample. Sample 162 had $140 \mathrm{~cm}^{2}$ surface (one side); the leachant volume used was $70 \mathrm{~cm}^{3}$ for a volume-to-surface ratio of $0.5 \mathrm{~cm}$. (The use of a ratio of 10 as the IAEA recommends was not practical because of the large volume of leachate that

*EAL Corporation, Richmond, CA, performed radiochemical analyses for Sr-90 and $\mathrm{Pu}-239,240$ on both the leachate and the leached coating residue. 
would be produced. Since the total amount of leachate was to be sent out for analysis, the total volume was limited to less than $2 \mathrm{~L}$. After gamma counting, the leachate was acidified to about $2 \mathrm{~N}$ with nitric acid and combined with previous specimens in a polyethylene bottle. The acidified leachate volume plus the wash (performed at EAL Corp) from the polyethylene bottle in which the leach coating was shipped after the coating was removed for analysis totaled $1370 \mathrm{~mL}$. The total volume of delonized water leachant was $1050 \mathrm{~mL}$ for a cumulative volume-to-surface ratio of $7.5 \mathrm{~cm}$.

Table 4.6 1ists the data on the activities of Cs-134,137, Sr-90, and Pu-239,240 from the leachate and residue of the TMI coating sample from bag 162.

The activities listed in Table 4.6 are for the TMI sample with the highest activity, according to the gamma counting results ilsted in Table 4.5. Assuming that the $\mathrm{Cs}$ and $\mathrm{Sr}$ activities in the five coating pieces are distributed proportionally according to the totals in Table 4.6 and the gamma counts in Table 4.5, the total activity of the five coating pieces considered as a batch can be calculated.

$$
\begin{aligned}
& \text { Total Cs-137 activity }=\frac{52 \mu \mathrm{Ci} \mathrm{Cs}-137}{250 \mathrm{mrem}}(3.5+230+250+150+4.0) \mathrm{mrem} \\
& \text { Total Cs-137 activity }=130 \mu \mathrm{Ci} \\
& \text { Total Sr-90 activity }=\frac{2.28 \mu \mathrm{Ci} \mathrm{Sr}-90}{250 \mathrm{mrem}}(3.5+230+150+250+4.0) \mathrm{mrem}
\end{aligned}
$$$$
\text { Total Sr-90 activity }=5.8 . \mu \mathrm{Ci}
$$

These estimated total activities along with the corresponding specific and volumetric activities are listed in Table 4.7 .

The limits for Class A radwaste in 10 CFR Part 61, Table 2, are $1 \mu \mathrm{Ci} / \mathrm{cm}^{3} \mathrm{Cs}-137$ and $0.04 \mu \mathrm{Ct} / \mathrm{cm}^{3} \mathrm{sr}-90$. The estimated volumetric activities in Table 4.7 exceed these limits for both of these radionuclides. If these activities approximate those of the strippable coating, radwaste from GDE, it would be Class $B$ under 10 CFR Part 61 and hence would require stabilization.

The data in Table 4.6 and 4.7 were used to calculate the expected dose that a 55-gal drum of the TMI coating considered as a batch could be expected to receive. This calculation, which follows the procedures presented in Reference 45, is shown in Appendix $C$. The cumulative dose is estimated to be approximately 2 Mrad in 300 yrs. 


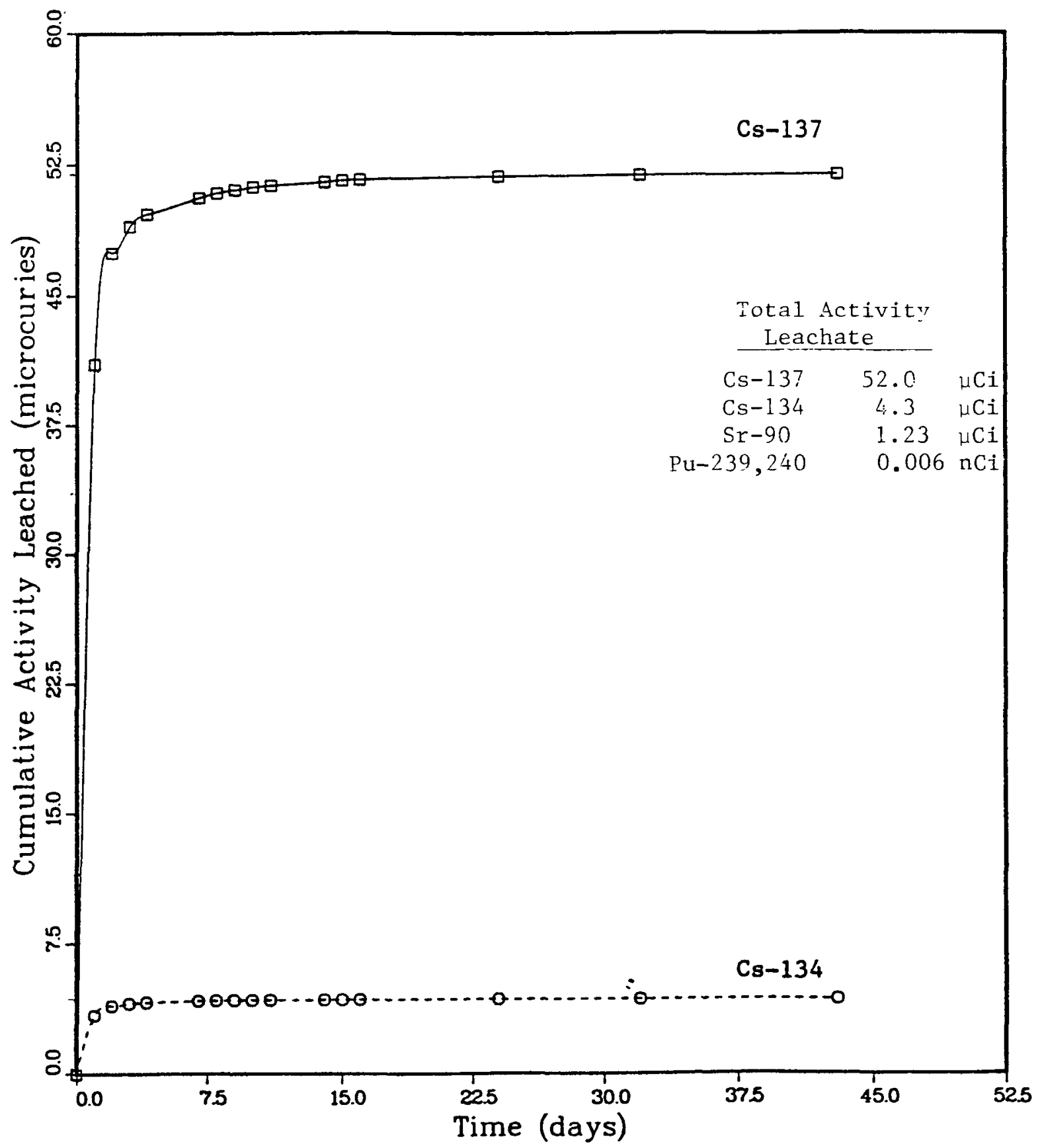

Figure 4.9 Leach test results for a TMI strippable coating sample. Cumulative leached activity for Cs-137 and Cs-134 are plotted vs time. Data points indicate leachate change intervals. The total leached activities for $\mathrm{Cs}-137$, $\mathrm{Cs}-134, \mathrm{Sr}-90$ and $\mathrm{Pu}-239,240$ are listed. 
Table 4.6

Activity Distributiona Between Leachate and Coating for a Sample Coating ${ }^{b}$ From the TMI-2 Gross Decontamination Experiment

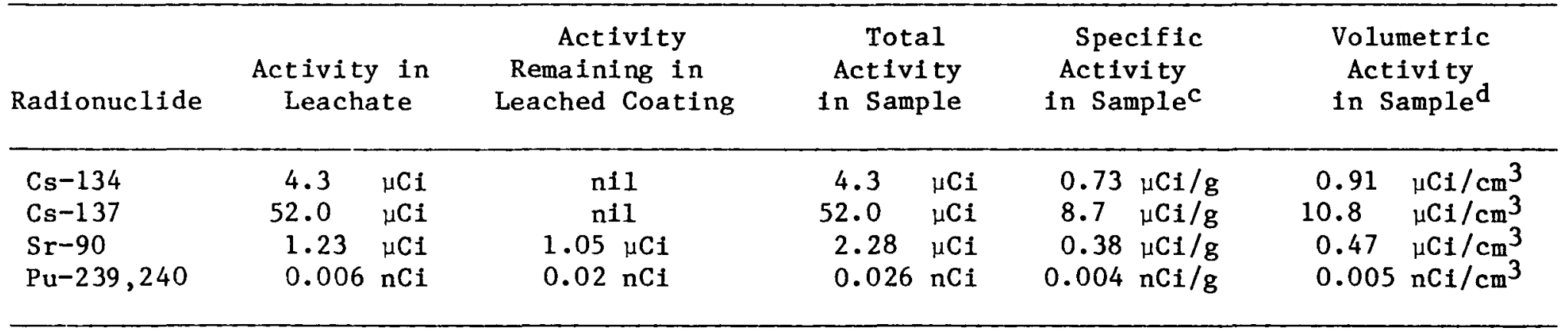

${ }^{a}$ The Cs-134,137 activities were determined by gamma spectroscopy at BNL.

The $\mathrm{Sr}$ and $\mathrm{Pu}$ activities were determined by EAL Corp. Richmond, CA.

${ }^{3}$ The sample came from bag 162 as 1 isted in Table 4.5. The coating is ALARA 1146 Decon, product of Imperial Professional Coatings Corp., New Orleans, LA.

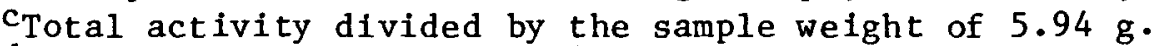

Specific activity in units of $\mu \mathrm{Ci} / \mathrm{g}$ multiplied by the density of the set coating in $\mathrm{g} / \mathrm{cm}^{3}$. The density used is $1.24 \mathrm{~g} / \mathrm{cm}^{3}$ as calculated from the Physical Properties fact sheet for ALARA 1146. 
Table 4.7

The Estimated Activities ${ }^{a}$ of $\mathrm{Cs}^{-1} 137$ and $\mathrm{Sr}-90$ in the Five TMI Coating Pieces Considered as a Batch

\begin{tabular}{|c|c|c|c|}
\hline Radionuclide & $\begin{array}{c}\text { Total } \\
\text { Activity } \\
\text { (Estimated) }\end{array}$ & $\begin{array}{l}\text { Specific } \\
\text { Activity }\end{array}$ & $\begin{array}{r}\text { Volumetric } \\
\text { Activity }\end{array}$ \\
\hline$C s-137$ & $130 \mu \mathrm{CI}$ & $4.5 \mu \mathrm{Ci} / \mathrm{g}$ & $5.6 \mu \mathrm{Cl} / \mathrm{cm}^{3}$ \\
\hline Sr-90 & $5.8 \mu \mathrm{Ci}$ & $0.20 \mu \mathrm{Ci} / \mathrm{g}$ & $0.25 \mu \mathrm{Ci} / \mathrm{cm}^{3}$ \\
\hline \multicolumn{4}{|c|}{$\begin{array}{l}\text { aEstimated assuming a proportional distribution in the five TMI } \\
\text { samples listed in Table } 4.5 \text { to the measured activities in sample } 162 \\
\text { as Iisted in Table } 4.6 \text {. } \\
\text { bTotal activity divided by the batch weight of } 29.29 \mathrm{~g} \text {. } \\
\text { c Specific activity in } \mu \mathrm{Ci} / \mathrm{g} \text { times the density }\left(1.24 \mathrm{~g} / \mathrm{cm}^{3}\right) \text { of } \\
\text { the ALARA } 1146 \text { coating as calculated from the Physical Properties } \\
\text { fact sheet. }\end{array}$} \\
\hline
\end{tabular}

\subsubsection{Biodegradation Testing of TMI Strippable Coating}

Biodegradation of TMI strippable coating samples in backfill soils from the Barnwell and Hanford land burial sites was monitored by $\mathrm{CO}_{2}$ generation. The experimental procedures using the spectal flasks(36) were the same as those in the scoping tests of Section 4.1.5. The sample size in these tests was greatly reduced to assure uniform mixing of samples with soil and equal sample surface areas exposed to direct soil contact in each test. Each TMI coating sample consisted of 10 pieces, each $1 \mathrm{~cm}^{2}$, cut from the specimen in bag 52 (Table 4.5). Samples were mixed with $100 \mathrm{~g}$ of moist soil from the Barnwell and Hanford land burial sites and loaded into the special flasks. Soll controls of $100 \mathrm{~g}$ of each of the same soils and a sample control moistened with $1-\mathrm{mL}$ water were also prepared. The soil moisture contents were raised to $12.5 \%$ for the Hanford soll and to $9.8 \%$ for the Barnwell soil from as received values of $8.9 \%$ and $4.2 \%$, respectively. (46) (The lower moisture holding ability of the Barnwell soil appeared to be a result of its coarse texture and sandy characteristics.)

Results of the TMI blodegradation tests are listed in Table 4.8 and shown in Figures 4.10-4.12. Figure 4.10 shows the $\mathrm{CO}_{2}$ generation (mg) vs time from the samples in Barnwell, $B$, and Hanford, $H$, solls. Figures 4.11 and 4.12 show the $\mathrm{CO}_{2}$ generation expressed as percent carbon in the sample. (The value of $52.3 \% \mathrm{C}$ measured for the purchased 1146 coating used in the scoping tests was also used in these tests. The actual TMI coating samples were not analyzed for total carbon.) The shaded area in these figures represent the range of probable biodegradation based on the data, which is the lower boundary, and the curve produced by dividing each data point value by 
0.6 , which defines the upper boundary. This probable range is based on observations $(39,40)$ that as little as $60 \%$ of the carbon in a material undergoing biodegradation may be evolved as $\mathrm{CO}_{2}$, the remainder being incorporated into increased microbe mass or excreted as metabolic waste products other than $\mathrm{CO}_{2}$. Table 4.8 summarizes the data for the biodegradation experiment monitored by $\mathrm{CO}_{2}$ generation plus data on the weight loss that occurred during the 208 days of the test. Biodegradation measured by weight loss falls in the range of expected biodegradation from the $\mathrm{CO}_{2}$ measurements.

Table 4.8

Biodegradation Test Results for Strippable Coating Samples From the TMI-2 Reactor Building Gross Decontamination Experiment

\begin{tabular}{|c|c|c|c|c|c|c|}
\hline Sample & $\begin{array}{c}\text { Initial } \\
\text { Weight } \\
W_{O} \\
(g)\end{array}$ & $\begin{array}{c}\text { Final } \\
\text { Weight } \\
W_{f} \\
(g)\end{array}$ & $\begin{array}{c}\text { Biogenically } \\
\text { Generated } \\
\mathrm{CO}_{2} \\
(\mathrm{mg})\end{array}$ & $\% \mathrm{ca}^{\mathrm{a}}$ & $\begin{array}{l}\% c^{b} \\
0.6\end{array}$ & $\frac{W_{0}-W_{f}}{W_{0}} \times 100$ \\
\hline $\begin{array}{l}\text { B } \\
\text { H } \\
\text { Control }\end{array}$ & $\begin{array}{l}0.544 \\
0.554 \\
0.554\end{array}$ & $\begin{array}{l}0.526 \\
0.505 \\
0.546\end{array}$ & $\begin{array}{l}48.62 \\
94.86 \\
\text { None }\end{array}$ & $\begin{array}{c}4.65 \\
8.92 \\
0\end{array}$ & $\begin{array}{c}7.75 \\
14.87 \\
0\end{array}$ & $\begin{array}{l}3.31 \\
8.84 \\
1.44\end{array}$ \\
\hline
\end{tabular}

a From the biogenically generated $\mathrm{CO}_{2}$ data and the measured $52.3 \% \mathrm{C}$ content of the coating used in the scoping tests, Section 4.1.5.

$b_{\text {The estimated upper } 11 m i t}$ of biodegradation based on $\mathrm{CO}_{2}$ generation and observations, References 39 and 40 , that as little as $60 \%$ of the available carbon may be evolved as $\mathrm{CO}_{2}$ during biodegradation.

cPercent biodegradation from the inttial and final welght following 208 days of biodegradation in soll at $20-24^{\circ} \mathrm{C}$.

These results support the results obtained in the scoping biodegradation tests that the ALARA 1146 strippable coating used at TMI biodegrades readily in soil. The rate of biodegradation is initially rapid and decreases with time. The biodegradation of this material proceeds faster in Hanford soil than in Barnwell soll under the conditions of these tests. The differences may be due to the greater moisture holding ability of Hanford soll relative to Barnwell soil, or it may be related to the fact that Hanford soil contains more soluble ions, $(46)$ and therefore, presumably more of the required trace minerals needed for microbe growth, or it may be a combination of these plus other factors. The biodegradability of the ALARA 1146 coating as reflected by these test results shows that, under 10 CFR Part 61 , Class B or C strippable coating radwaste would have to be isolated from the burial trench environment to prevent microbe attack. 


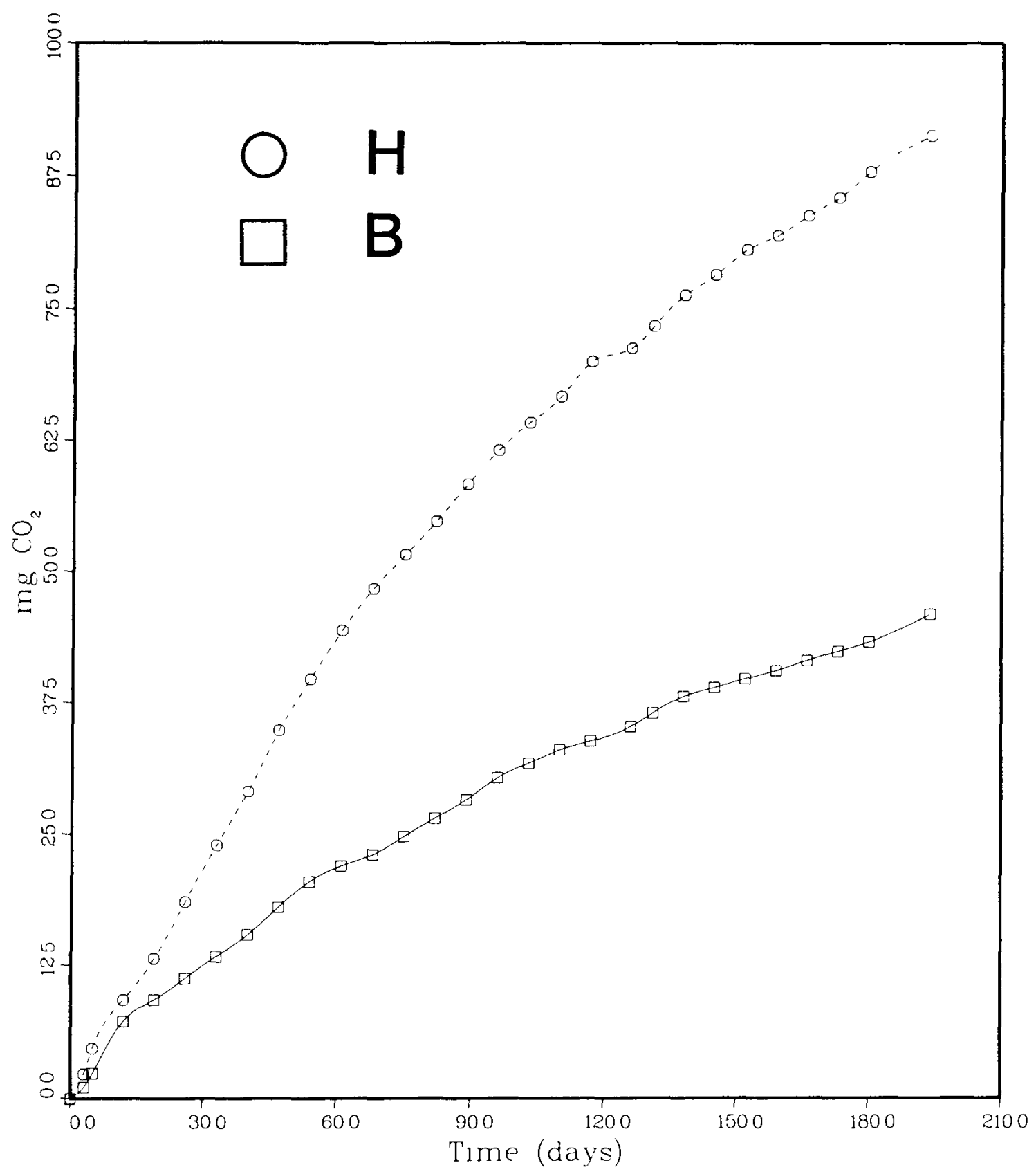

Figure 4.10 Biodegradative $\mathrm{CO}_{2}$ gas evolution from TMI strippable coating material in Barnwell and Hanford soils. 


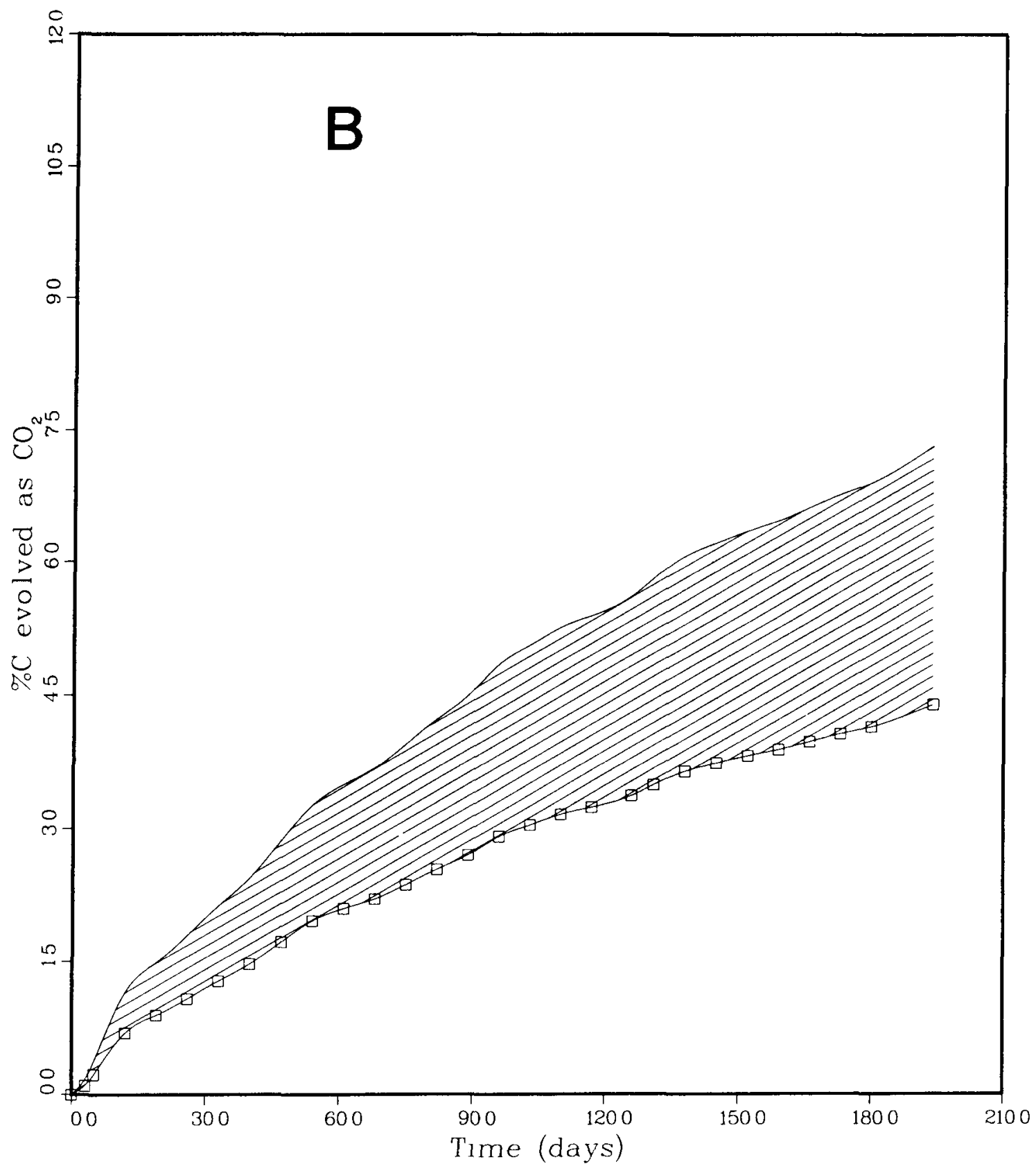

Figure 4.11 Probable range of biodegradation of TMI strippable coating in Barnwell soil. 


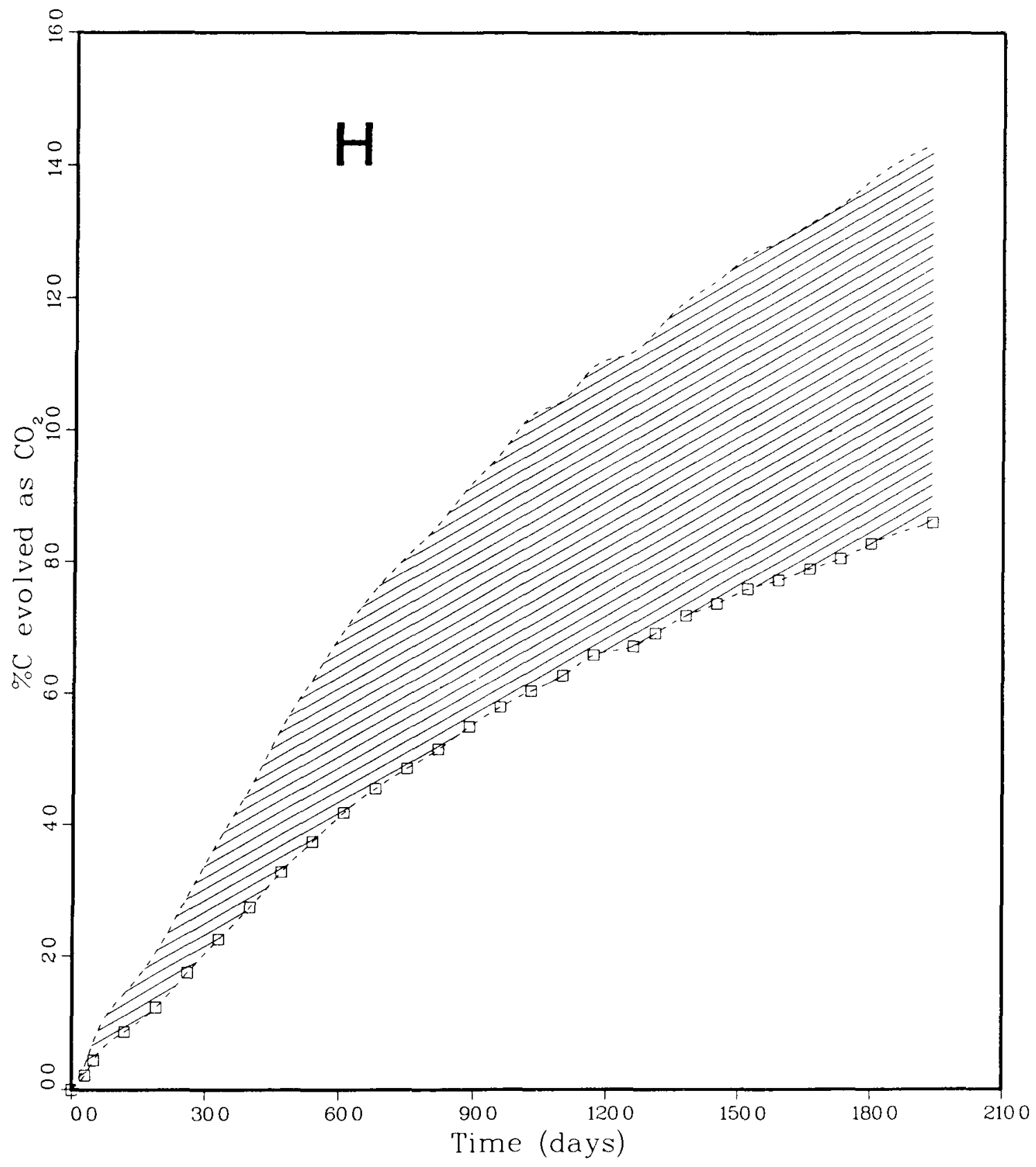

Figure 4.12 Probable range of biodegradation of TMI strippable coating in Hanford soil. 


\subsubsection{Summary of TMI Strippable Coating Sample Tests}

Leach testing of the sample of ALARA 1146 coating from the TMI-2 GDE showed that Cs leaches from the coating immediately upon contact with water. The Sr activity was portioned more or less equally between the coating and the leachate whereas, only about a quarter of the Pu activity was leached. These results are consistent with the scoping radionuclide leach testing results and added the knowledge that $\mathrm{Pu}$ tends to be retained on the coating, at least for the low activity levels measured here.

The TMI coating samples blodegraded readily in Barnwell and Hanford land burial backfill solls. This susceptibility to microbe attack dictates that coating radwaste classed as $B$ or C under 10 CFR Part 61 would require stabilization.

Decontamination using the ALARA 1146 strippable coating was shown to be effective (DF about 100) on the epoxy painted floor of the TMI-2 reactor building. $(9,10)$ Its effectiveness in removing debris following low pressure water flushing was the best of the decontamination methods tested. Use of the strippable coating generated about $0.64 \mathrm{ft}^{3}$ of solid compactible waste per $100 \mathrm{ft}^{2}$ of application. Compaction would allow coating waste from decontaminating 2000-2500 $\mathrm{ft}^{2}$ to be disposed of in one 55-gal drum.

The contamination taken up by the coating application in the decontamination test produced waste which, if compacted to fill a 55-gal drum, would have a contact radiation reading of less than $5 \mathrm{rem} / \mathrm{h}$. (10) Equation 2.1 and the appropriate C.F. $(22,23)$ for a compacted 55 -gal drum of Normal Unit 2 Radwaste allows calculation of the activity contained in the hypothetical drum.

$$
\begin{aligned}
& \text { Activity }=(0.557 \mathrm{mCi} \mathrm{h} / \mathrm{mrem})(5000 \mathrm{mrem} / \mathrm{h}) \\
& \text { Activity }=2800 \mathrm{mCl}
\end{aligned}
$$

This activity in a 55-gal drum $\left(210,000 \mathrm{~cm}^{3}\right)$ results in an activity density of $13.3 \mu \mathrm{Ci} / \mathrm{cm}^{3}$, or $10.7 \mu \mathrm{Ci} / \mathrm{g}$ based on the $1.24 \mathrm{~g} / \mathrm{cm}^{3}$ density for the coating. This activity is consistent with, though higher than, the measured activities in Tables 4.6 and 4.7 .

The measured activity on the strippable coating radwaste used for decontamination in the GDE provides evidence that such decontamination applications may be expected to result in Class $B$ radwaste order 10 CFR Part 61 . As of this writing, it is not known whether the coating will be used for decontamination activities beyond its evaluation in the GDE testing. It is being used as a protective coating over cleaned surfaces in the upper part of the reactor building including the 305 and $347-\mathrm{ft}$ elevations and the polar crane. Class B strippable coating radwaste would require stabilization under 10 CFR 
Part 61. Imperial Professional Coating has experimental solidification systems* for this purpose; however, these solidification systems have not yet been evaluated for compliance with the stability provisions of 10 CFR Part 61 .

*Personal communication between J. Adams (BNL) and H. Lomasney (Imperial), July 30, 1982, "Solidification Systems for Strippable Coatings." 
. 
5. REFERENCES

1. TPO/TMI-007, "Three Mile Island Unit 2 Recovery Project Technical Plan for Reactor Building Gross Decontamination," Bechtel National, Incorporated, May 1981 .

2. TPO/TMI-009, "Three Mile Island Unit 2 Recovery Project Decontamination Techniques Test Program," Bechtel National, Incorporated, May 1981.

3. Final Programmatic Enviromental Impact Statement Related to Decontamination and Disposal of Radioactive Wastes Resulting From May 28, 1979 , Accident Three Mile Island Nuclear Station, Unit 2," U.S. Nuclear Regulatory Commission," Office of Nuclear Reactor Regulation, NUREG-0683, March 1981.

4. D. L. Geifer, "Planning for the TMI-2 Reactor Building Decontamination Experiment," Decontamination of Nuclear Facilities 2, International Joint Topica1 Meeting ANS-CNA, Chapter 5, 1-10, Sept ember 1982.

5. D. Leigh, L. J. Coe, and G. R. Eidam, "Data Acquisition and Characterization for LSDE at TMI-2," Ibid, 11-26.

6. J. V. Gilbert, "TMI-2 Containment Entry Program," Ibid, 27-46.

7. H. L. Hondorp, "Planning for the TMI-2 Reactor Coolant System Decontamination," Ibid, 69-80.

8. M. Drackley, "Preliminary Analysis of Reactor Building Gross Decontamination Experiment Core Boring Samples," Memorandum to L. H. Barrett, TMI Program Office, USNRC, June 17, 1982.

9. D. R. Dougherty and R. E. Barletta, "Trip Report - Meeting at TMI on June 18, 1982," Memorandum to File, Brookhaven National Laboratory, Nuclear Waste Management Division, June 30, 1982.

10. P. R. Bengel and R. L. Mason, "Results of the Gross Decontamination Experiment and Implications for Future Decontamination Activity," Decontamination of Nuclear Facilities 2, International Joint Topical Meeting ANS-CNA, Chapter 5, 47-68, September 1982.

11. K. J. Hofstetter, K. J. Hitz, C. G. Lookabil1, and S. J. Eichfeld, "Submerged Demineralizer System Design, Operation and Results," Ibid, 81-90.

12. R. S. Daniels and J. M. Rodabugh, "Waste Management Planning for the Recovery of TMI-2," Ibid, 91-100.

13. H. Dieckamp, "March 28, 1979 Plus 42 Months or a Status Report on the TMI-2 Cleanup Program," Decontamination of Nuclear Facilities, Keynote Addresses, International Joint Topical Meeting, ANS-CNA, September 1982. 
14. J. Raloff, "TV at TMI: Hard Core Rubble," Science News 122 (5), 68, 1982 .

15. M. Gold, "Inside Three Mile Island," Science 82 (8), 16, 1982.

16. R. Lo, and R. Bellamy, "Regulatory Aspects of TMI Cleanup" Decontamination of Nuclear Facilities 1, International Joint Topical Meeting ANS-CNA, Chapter 1, 1-5, September 1982.

17. Memorandum of Understanding Between USNRC and USDOE Concerning the Removal and Disposition of Solid Nuclear Wastes From Cleanup of the Three Mile Island Unit 2 Nuclear Plant, Federal Register 47, 16229-16230, Apri1 15, 1982 .

18. R. W. Sexton, "NRC Pre-Notification Rule in Effect: TMI Officials Relate Time Consuming Procedure," Hazardous Materials Transportation 5 (7), July 1982 .

19. R. S. Daniels, in an answer to a question on radwaste volumes yet to be generated in the TMI-2 cleanup after his presentation of the paper in Reference 12. He was quoted in a newspaper article: W. Immen, "Three-Mile A Blast is a Risk in Cleanup," The Globe and Mail, 1, September 16,1982 .

20. T. C. Johnson and H. Lowenberg, "Classification of TMI Wastes," Waste Management ' 82 , in Proceedings of the Symposium on Waste Management at Tuscon, Arizona, March 8-11, 1982, Volume II, 121-131, 1982 .

21. H. Lowenberg, "TMI-II Waste Management - DOE Programs for Handling Some Special Wastes," Memorandum to File, U.S.N.R.C., office of Nuclear Material Safety and Safeguards, September 1, 1982 .

22. Memorandum, S. R. Frey to J. Winkel, "Mathematical Factors for Curie Estimations for Unit-2 Radwste," GPU Nuclear Inter-Office Memorandum 9240-956, May 28, 1982 .

23. Memorandum, S. R. Frey to R. Hahn, "Revision of Correction Factors for Unit II Radwaste," GPU Nuclear Inter-Office Memorandum 9240-1038, June 30,1982 .

24. Bechtel Northern Corporation, "Controlled Air Incineration Conceptual Design Study," GEND-021, EG and G Idaho, Inc., January 1982.

25. B. J. Newby and K. L. Rohde, "Decontamination of Protective Coatings Following a Loss of Coolant Accident," in Proceedings of the First International Symposium on Decontamination of Nuclear Installations, pp. $117-128,1967$.

26. Bechtel Northern Corp., "Decontamination Experiment Post Execution Analysis," June, 1982. 
27. J. A. Mock, "Strippable Coatings," Materials Engineering 90(3), 86-89 (1979).

28. B. W. Ariss, and C. R. Thomas, "The Use of Coatings to Facilitate Decontamination," Proceedings of the First International Symposium on Decontamination of Nuclear Installations, 55-64, 1967

29. J. F. Remark, "Plant Decontamination Methods Review," Electric Power Research Institute, Technical Planning Study, TPS 78-816, EPRI NP-1168, May 1981.

30. C. S. Lacy, "Decontamination of a Fueling Machine Contaminated by Irradiated Fuel Debris," Presented at Corrosion/78, Paper No. 36, Houston, TX, March 1978.

31. S. K. Robev, T. B. Sumerska, S. L. Todorov, D. K. Krstanov, T. I. Marinova, "A Method for Deactivating Contaminated Surfaces by Film," in Proceedings Series-Practices in Treatment of Low and Intermediate Level Radioactive Wastes," pp. 751-757, IAEA, Vienna, Austria, 1966.

32. A. Catherall and B. W. Ariss, "The 'DETEX' Technique of Decontamination," U.K.A.E.A. Report AHSB(S)R57, 27-39, 1963.

33. 0. A. Bernaola and A. Filevich, "Fast Drying Strippable Protective Cover for Radioactive Decontamination," Health Physics, Pergammon Press, Vol. $19,685-687,1970$.

34. Personal Communication, letter, between R. Barletta and H. L. Lomasney of Imperial Professional Coatings, Inc., June 7, 1982.

35. Radiologica1 Health Handbook, Bureau of Radiological Health, U.S. Department of Health, Education, and Welfare, 122, January 1970.

36. R. Bartha and D. Pramer, "Features of a Flask and Method for Measuring the Persistence and Blological Effects of Pesticides in Soils," Soil Science $100(1)$, 68-70 (1965).

37. R. H. Brink, "Biodegradation of Organic Chemicals in the Enironment," pp. 75-100, in Environmental Health Chemistry: Proceedings of a 1979 Symposium on Chemical and Environmental Agents and Potential Human Hazards, Ann Arbon Science Press, Ann Arbor, MI, 1981.

38. H. G. Schlege1, "Production, Modification, and Consumption of Atmospheric Trace Gases by Microorganism," Tellus 24, 11-20 (1974).

39. G. Stotsky, "Microbial Respiration," Methods of Soil Analysis: Part 2, Chemical and Microbiological Properties, pp. 1150-1572, American Society and Agromony, Inc. Madison, WI, 1965. 
40. P. A. Gilbert, "Blodegradation Tests: Use and Value," pp. 35-45 in Biotransformations and the Fate of Chemicals in an Aquatic Environment: Procedures Workshop, 1980.

41. D. R. MacKenzie, F. Vaslow, D. Dougherty, and S. Chan, "Technical Factors Affecting Low Level Waste Form Acceptance Requirements," BNL-NUREG-31536, Draft Report, 33-38, August 1982 .

42. Radiation Effects on Organic Materials, R. 0. Bolt and J. G. Carrol1, Editors, Academic Press, New York, 1963.

43. Irradiation of Polymers, R. F. Gould, Editor, American Chemfcal Society Advances in Chemistry Series, 66, Washington, D.C., 1967.

44. Southwest Research Institute, 6220 Culebra Road, P.0. Drawer 28510, San Antonio, TX, 78284; Project No. 02-5424-002, June/July 1979; The report is also available from Imperial Professional Coatings, Inc, , P.0. Box 29077, New Orleans, LA, 70189, as Technical Report No. 311-1-79.

45. K. J. Swyler, R. E. Barletta, and R. E. Davis, "Review of Recent Studies of the Radiation Induced Behavior of Ion Exchange Media," BNL-NUREG-28682, Draft Report, November 1980.

46. P. L. Piciulo, C. E. Shea, and R. E. Barletta, "Analyses of Soils at Low Level Radioactive Waste Disposal Sites," BNL-NUREG-31388, Draft Report, June 1982. 
APPENDIX A

10 CFR PART 61.55: RADIOACTIVE WASTE CLASSIFICATION

FOR DISPOSAL IN SHALLOW LAND BURIAL 
disposal site before they leave the site boundary.

\section{\$61.54 Alternative requirements for design and operations.}

The Commission may, upon request or on its own initiative, authorize provisions other than those set forth in $\$ \$ 61.51$ through 61.53 for the segregation and disposal of waste and for the design and operation of a land disposal facility on a specific basis, if it finds reasonable assurance of compliance with the performance objectives of Subpart C of this part.

\section{\$61.55 Waste classification.}

(a) Classification of waste for near surface disposal.

(1) Considerations. Determination of the classification of radioactive waste involves two considerations. First, consideration must be given to the concentration of long-lived radionuclides (and their shorter-lived precursors) whose potential hazard will persist long after such precautions as institutional controls, improved waste form, and deeper disposal have ceased to be effective. These precautions delay the time when long-lived radionuclides could cause exposures. In addition, the magnitude of the potential dose is limited by the concentration and availability of the radionuclide at the time of exposure. Second, consideration must be given to the concentration of shorter-lived radionuclides for which requirensents on institutional controls, waste form, and disposal methods are effective.

(2) Classes of waste. (i) Class A waste is waste that is uoually segregated from other waste classes at the disposal site. The physical form and characteristics of Class $A$ waste must meet the minimum requirements set forth in $\$ 61.56(\mathrm{a})$. If Class $A$ waste also meets the stability requirements set forth in $\$ 61.56(\mathrm{~b})$, it is not necessary to segregate the waste for disposal.

(ii) Class B waste is waste that must meet more rigorous requirements on waste form to ensure stability after disposal. The physical form.and characteristics of Class B waste nust meet both the minimum and stability requirements set forth in $\$ 61.50$.

(iii) Class $\mathrm{C}$ waste is waste that not only must meet more rigorous requirements on waste form to ensure stability but also requires additional measures at the disposal facility to protect against inadvertent intrusion. The physical form and characteristics of Class C waste must meet both the minimum and stability requirements set forth in $\$ 61.58$. (iv) Waste that is not generally acceptable for near-surface disposal is waste for which waste form and disposal methods must be different, and in general more stringent, than those specified for Class $C$ waste. In the absence of specific requirements in this part, proposals for disposal of this waste may be submitted to the Commission for approval, pursuant to $\$ 61.58$ of this part.

(3) Classification determined by longlived radionuclides. If radioactive waste contains only radionuclides listed in Table 1, classification shall be determined as follows:

(i) If the concentration does not exceed 0.1 times the value in Table 1 . the waste is Class $A$.

(ii) If the concentration exceeds 0.1 times the value in Table 1 but does not exceed the value in Table 1 , the waste is Class C.

(iii) If the concentration exceeds the value in Table 1, the waste is not generally acceptable for near-surface disposal.

(iv) For wastes containing mixtures of radionuclides listed in Table 1 , the total concentration shall be determined by the sum of fractions rule described in paragraph (a)(7) of this section.

\section{TABLE 1}

\begin{tabular}{|c|c|}
\hline Radtomuclide & $\begin{array}{c}\text { Concen } \\
\text { tration } \\
\text { cunes per } \\
\text { cubuc } \\
\text { molor }\end{array}$ \\
\hline 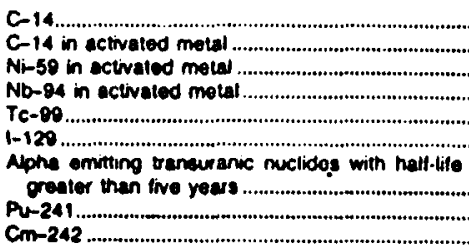 & $\begin{array}{c}8 \\
80 \\
220 \\
0.2 \\
3 \\
0.08 \\
1100 \\
13,500 \\
120,000\end{array}$ \\
\hline
\end{tabular}

'Units are nanocunos por gram.

(4) Classification determined by short. lived radionuclides. If radioactive waste does not contain any of the radionuclides listed in Table 1 . classification shall be determined based on the concentrations shown in Table 2. However, as specified in paragraph (a)(6) of this section. if radioactive waste does not contain any nuclides listed in either Table 1 or 2 , it is Class A.

(i) If the concentration does not exceed the value in Column 1. the waste is Class $A$.

(ii) If the concentration exceeds the value in Column 1. but does not exceed the value in Column 2, the waste is Class B.

(iii) If the concentration exceeds the value in Column 2. but does not exceed the value in Colunn 3 , the waste is Class C. (iv) If the concentration exceeds the value in Column 3, the waste is not generally acceptable for near-surface disposal.

(v) For wastes containing mixtures of the nuclides listed in Table 2 , the total concentration shall be determined by the sum of fractions rule described in paragraph (a)(7) of this section.

TABle 2

\begin{tabular}{|c|c|c|c|}
\hline \multirow{2}{*}{ Padionuclide } & \multicolumn{3}{|c|}{$\begin{array}{l}\text { Concentration, curios } \\
\text { por cubtc nimiter }\end{array}$} \\
\hline & Cot. 1 & col. & $\underset{3}{\text { Col. }}$ \\
\hline 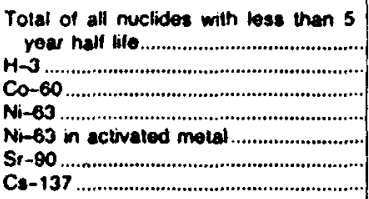 & $\begin{array}{c}700 \\
40 \\
700 \\
3.5 \\
35 \\
0.04 \\
1\end{array}$ & $\begin{array}{r}17 \\
17 \\
17 \\
70 \\
700 \\
150 \\
44\end{array}$ & $\begin{array}{r}11 \\
17 \\
11 \\
700 \\
7000 \\
7000 \\
4600\end{array}$ \\
\hline
\end{tabular}

- Thore are no limms established for theso radionuclidos in Class $B$ of $C$ wastes. Practucal considerations such ay the

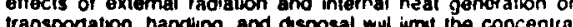
tons lor these wastes. These wastes shall b Class uniese the class unlese ine concentratons of other nuclides in Table nucliotos.

(5) Classification determined by both long- and short-lived radionuclides. If radioactive waste contains a mixture of radionuclides, some of which are listed in 'ruble 1, and some of which are listed in Table 2. classification sbull be determined as follows:

(i) If the concentration of a nuclide listed in Table 1 does not exceed 0.1 times the value listed in Tuble 1 , the class shall be that determined by the concentration of nuclides listed in Table 2.

(ii) If the concentration of a nuclide listed in Table 1 exceeds 0.1 limes the value listed in Table 1 but does not exceed the value in Table 1 , the waste shall be Class $C$, provided the concentration of nuclides listed in Table 2 does not exceed the value shown in Column 3 of Table 2.

(6) Classification of wastes with radionuclides other than those listed in Tables 1 and 2 . If radionctive waste does not contain any nuclides listed in either Table 1 or 2 , it is Class $A$.

(7) The sum of the fractions rule for mixtures of radionuclides. For determining classification for waste that conlains a mixture of radionuclides, it is necessary to determine the sum of fractions by dividing each nuclide's concentration by the appropriate limil and adding the resulting values. The appropriate limits must all be taken from the same column of the same table. The sum of the fractions for the column must be less than 1.0 if the waste class is to be determined by that column. Example: $A$ wuste contuins $\mathrm{Sr}-90$ in a 
concentration of $50 \mathrm{Cl} / \mathrm{m}^{3}$ and Cs-137 in a concentration of $22 \mathrm{Cj} / \mathrm{m}^{2}$. Since the concentrations both exceed the values in Column 1. Table 2, they must be compared to Column 2 values. For $\mathrm{Sr}-90$ fraction $50 / 150=0.33$; for Cs -137 fraction, $22 / 44=0.5$; the sum of the fractions $=0.83$. Since the sum is less than 1.0, the waste is Class $B$.

(8) Determination of concentrations in wastes. The concentration of a radionuclide may be determined by indirect methods such as use of scaling factors which relate the inferred concentration of one radionuclide to another that is measured, or radionuclide material accountability. if there is reasonable assurance that the indirect methods can be correlated with actual measurements. The concentration of a radionuclide may be averaged over the volume of the waste. or weight of the waste if the units are expressed as nanocuries per gram.

\subsection{Waste characteristlcs.}

(a) The following requirements are minımum requirements for all classes of waste and are intended to facilitate handing at the disposal site and provide protection of health and safety of personnel at the disposal sitc.

(1) Waste must not be packnged for disposal an cardboard or fiberboard boxes.

(2) Liquid waste must be solidified or packaged in sufficient absorbent material to absorb twice the volume of the liquid.

(3) Solid waste contaıning liquid shall contain as hittle free standing and noncorrosive liquid as is reasonably nchievable, but in no case shall the liquid exceed 1\% of the volume.

(4) Waste must not be readily capable of detonation or of explosive decomposition or reaction at normal pressures and temperatures, or of explosive reaction with water.

(5) Waste must not contain, or be capable of generating, quantitues of toxic gases, vapors, or fumes harmful to persons transporting, handling, or disposing of the waste. This does not apply to radioactive gaseous waste packaged in accordance with paragraph (a)(7) of this section.

(6) Waste must not be pyrophoric. Pyrophoric materials contained in waste shall be treated, prepared, and packaged to be nonflammable.

(7) Waste in a gaseous form must be packaged at a pressure that does not exceed 1.5 atmospheres at $20^{\circ} \mathrm{C}$. Total activity must not exceed 100 curies per container

(B) Waste contoinung hazardous. biological, pathogenic. or infectious material must be treated to reduce to the mnximum extent practicable the potential hazard from the nonradiological matcrials.

(b) The requirements in this section are intended to provide stability of the wastc. Stability is intended to ensure that the waste does not structurally degrade and affect overall stability of the site through slumping, collapse, or other fuilure of the disposal unit and thereby lead to water infiltration. Stabihty is also a factor in limiting exposure to an inndvertent intruder. since it provides a recogmizable and nondispersible waste.

(1) Waste must have structural stability. A structurally stable waste form will generally maintain its physical dimensions and its form, under the expected disposal conditions such as weight of overburden and compaction equipment, the presence of moisture. and microbial activily, and internal factors such as radiation effects and chemical changes. Structural stabulty can be provided by the waste form itself, processing the waste to a stable form, or placing the waste in a disposal container or structure that provides stability after disposal.

(2) Notwithstanding the provisions in $\$ \$ 61.56(a)(2)$ and $(3)$. lejuid wastes, or wastes conleining liquid, nust be converted into a form that contains as little free standing and noncorrosive liquid as is reasonably achievable, but in no case shull the liquid exceed $1 \%$ of the volume of the waste when the waste is in a disposal container designed to ensure stability, or $0.5 \%$ of the volume of the waste for waste processed to a stable form.

(3) Void spaces within the waste and between the waste and its package must be reduced to the extent practicable

\section{$\$ 61.57$ Labeling.}

Each package of waste must be clearly labeled to identify whether it is Class A waste, Class B waste, or class $C$ waste in accordance with $\$ 6155$

\$61.58 Alternative requirements for waste classification end characteristıcs.

The Commission may, upon request or on its own initiative, authorize other provisions for the classification and characteristics of waste on a specific basis, if, after evaluation, of the specific characteristics of the waste. disposal site, and method of disposal, it finds reasonable assurance of compliance with the performance objectives in Subpart C of this part.

$\$ 61.59$ Instly tional requirements.

(a) Land ownership Disposul of radionc live waste received from other persons may be permitted only on land owned in fee by the Federal or a State government.

(b) Institulional control. The land owner or custodial ngency shull carry out an instifutional control program to physicully control access to the disposal site following transfer of control of the disposal site from the disposal sitc operator. The institutional control program must also include, but not be limited to. carrying out an environmental monitoring program at the disposal sile, periodic surveillance. minor custodial care, and other requirements as determıned by the Commission, and administration of funds to cover the costa for these activities. The period of institutional controls will be determined by the Commission, but institutional controls may not be relied upon for more than 100 years following transfer of control of the disposal site to the owner.

\section{Subpart E-Financlal Assurances}

\section{$\$ 61.61$ Applicant qualifications and} assurances.

Each applicant shall show that it either possesses the necessary funds or has reasonable assurance of obtaining the necessary funds, or by a combination of the two, to cover the estumated costs of conducting all licensed activities over the planned operating life of the project, including costs of construction and disposal.

\section{$\$ 61.62$ Funding for disposal site closure} and stabilization.

(a) The applicant shall provide assurance that sufficient funds will be avalable to carry out disposal site closure and stabilization, including: (1) Decontamination or dismantlement of Land disposal facility structures, and (2) closure and stabilization of the disposal site 80 that following transfer of the disposal site to the site owner, the need for ongoing actuve maintenance is eliminated to the extent practicable and only minor custodial care, surveillance. and monitoring are required. These assurances shall be based on Commission-approved cost estimates reflecting the Commission-approved plan for disposal site closure and stabilization The applicant's cost estimates must take unto account total capital costs that would be incurred if an independent contractor were hired to perform the closure and stabilization work.

(b) In order to avold unnecessary duplication and expense, the Commission will accepl financial sureties that have been consolidated with earmarked financial or surety arrangements established to meet 


\section{APPENDIX B}

TECHNICAL DATA SHEET FOR ALARA 1146 DECON STRIPPABLE COATING 


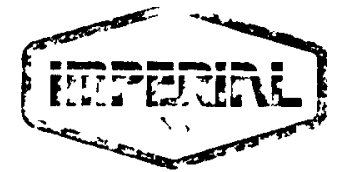

DESCRIPTION: One package, water borne, strippable coating.

RECOMMENDED USES: Decontaminating radioactive polluted areas. Apply over contaminated steel, concrete, wood, aluminum, or painted surfaces via spray or roll. Can be used for sealing (fixing) potential airborne contaminants, for protection of personnel from "smearable" contaminants. Also useful with beta emitters for "shielding" purposes. Because this product produces an easily compacted (solid) waste, the workload on radwaste processing facilities can be substantially reduced.

\section{PRODUCT DESIGN FUNCTION:}

1. Apply material over contaminated surface. While material is wet it attracts, absorbs and cnemically binds heavy metal isotopes. During application the coating migrates into micro voids of surface to contact contaminants. Upon cure, the product mechanically locks the contaminants into a polymer matrix. Stripping the film effectively cleans the substrate and produces a solid waste.

2. Apply material over clean surface to provide protective layer against future contamination.

3. Apply material over previously contaminated surfaces while still wet to inhibit potential airborne contamination during dry-out.

CAUTION: DO NOT FREEZE. Consult Imperial for specific instructions concerning high humidity applications. Refer to chart on reverse.

PHYSICAL PROPERTIES:

TYPE

COLOR

FLASH POINT

NUMBER OF COMPONENTS

POT LIFE@ $75^{\circ} \mathrm{F}$

DRYING TIME @ $75^{\circ} \mathrm{F}$ AND 75\% RH

SHELF LIFE

A. TO TOUCH (FOOT TRAFFIC) 24 hours

B. TO FULL CURE

NET WEIGHT - 1's

$$
5 \text { 's }
$$

PERCENT VOLUME SOLIDS

RECOMMENDED DRY FILM THICKNESS

THEORETICAL COVERAGE AT 25.0 MILS

THINNER

TEMPERATURE RESISTANCE

FIRE DATA (ASTM-E-84-77) @ 20-25 MILS

CHARCOAL FILTER

DECONTAMINATION FACTOR
Vinyl

Yellow

N/A

One

N/A

24 hours

4 months

9.0 pounds

45.0 pounds

$42 \%$

$20-30$ mils

$27 \mathrm{sq} \mathrm{ft} / \mathrm{gal}$

Water

$120^{\circ} \mathrm{F}$

20 (flame), 25 (fuel), 25 (smoke)

99.3\% efficiency after 2 hrs. @ 40FPM

face loading (methyl iodide)

30-100 (varies with substrate) 


\section{APPLICATION EQUIPMENT RECOMMENDATIONS:}

1. Airless - Standard industrial spray equipment (stainless steel parts desired) such as Graco or Binks, using a 30:1 pump ratio with $50-60$ psi inbound pressure and a .021 " to $.025^{\prime \prime}$ fluid tip with reversible cleaning head.

2 Roller $1 / 2$ " lambs wool with phenolic core.

SAFETY EQUIPMENT RECOMMENDATIONS: \#1146 is free of solvents and toxic materials. A particulate (gauze) mask is recommended to prevent inhalation of overspray. Consult Material Safety Data Sheet.

\section{APPLICATION PROCEDURE:}

1 Flush all equipment with fresh water prior to use.

2 Stir material thoroughly before and throughout application.

3. Do not thin except for workability, and then with no more than $10 \%$ by volume with fresh water.

4. Flush all equipment immediately after use with fresh water. Use butyl cellosolve or similar solvent for final cleaning.

\section{STORAGE CONDITIONS:}

$40^{\circ}$ to $90^{\circ} \mathrm{F}$. DO NOT FREEZE.

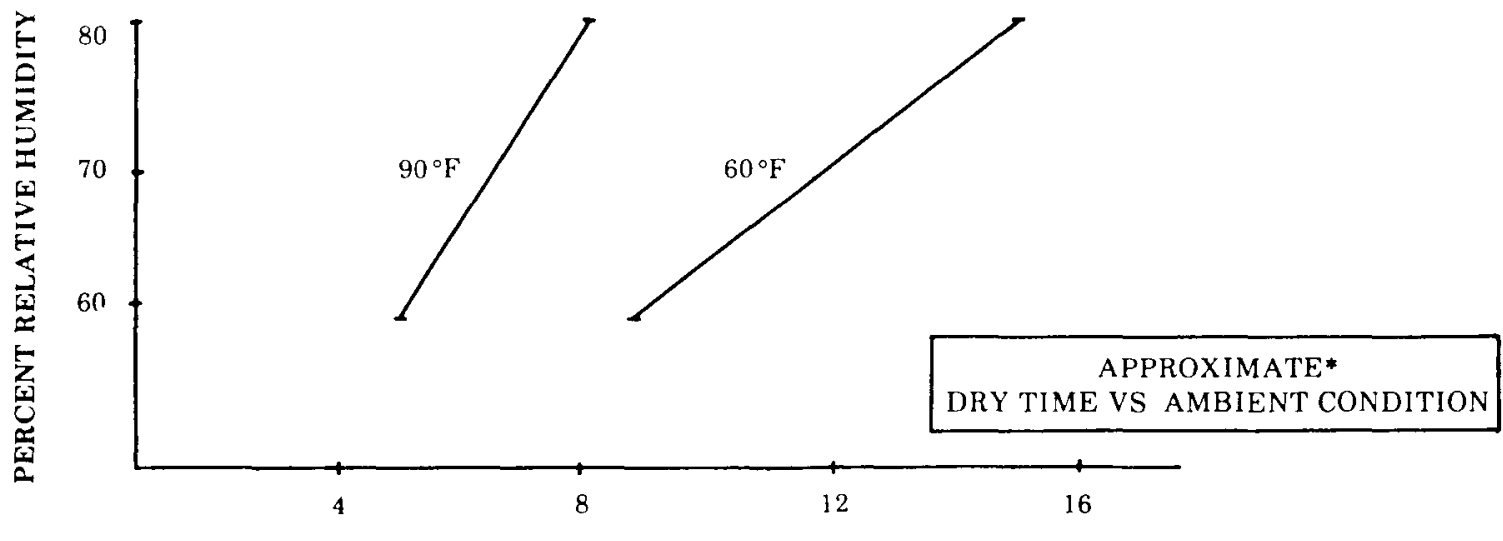

HOURS - SET TO TOUCH@ 50 MILSWET

* Drv time varies with air flow rate temperature, relative humidity, film thickness and substrate conditions

NOTE The technical data furnishell is true and accurate to the best of our knowledge houever no guarantee of accuracy is given or implied We guarantee our products to conform to Impenal Quality Control Standards We assume no responsibilities for its handling, use, storage, the results obtained or any injur or damage resulting from its use

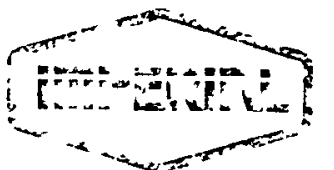





\author{
APPENDIX C \\ CUMULATIVE DOSE CALCULATIONS FOR THE \\ ALARA 1146 STRIPPABLE COATING SAMPLES FROM THE \\ TMI-2 REACTOR BUILDING GROSS DECONTAMINATION EXPERIMENT
}

The procedures in this Appendix, which are based on the analysis given in Appendix A of Reference 42, outline the methods used to calculate cumulative absorbed dose as a function of time.

Table C.l lists the radionuclides and pertinent decay parameters used for the calculations. A waste container is assumed to be a 55-gal drum the approximate dimensions of which are radius $=25 \mathrm{~cm}$ and height $100 \mathrm{~cm}$. The activity is assumed to be uniformly distributed throughout the volume of the drum. The activity densities used are from Table 4.6 and 4.7 .

Table C.1

Nuclides and Relevant Decay Data Used in

Calculation of Dose to Strippable Coating

\begin{tabular}{|c|c|c|c|c|}
\hline Radionuclide & $\left(y^{\lambda} r^{-1}\right)$ & $\begin{array}{l}t_{1 / 2} \\
(y r)\end{array}$ & $\begin{array}{l}\bar{E}^{\mathrm{a}} \\
\mathrm{MeV}\end{array}$ & $\left(\operatorname{rad} \mathrm{cm}^{2} \mathrm{~h}^{-1} \mathrm{mCi}^{-1}\right)$ \\
\hline $\begin{array}{l}\mathrm{Sr}-90 \\
(\mathrm{Y}-90)^{\mathrm{b}} \\
\mathrm{Cs}-134 \\
\mathrm{Cs}-137 \\
\mathrm{Pu}-239\end{array}$ & $\begin{array}{l}0.025 \\
(95) \\
0.33 \\
0.023\end{array}$ & $\begin{array}{l}28 \\
(.0073) \\
2.1 \\
30 \\
24,100\end{array}$ & $\begin{array}{l}0.200 \\
(0.931) \\
0.152 \\
0.195 \\
5.19\end{array}$ & $\begin{array}{l}\text { no } \gamma \\
(\text { no } \gamma) \\
8.7 \\
3.3 \\
\text { no } \gamma\end{array}$ \\
\hline \multicolumn{5}{|c|}{$\begin{array}{l}\text { a Reference } 1 \text {. } \\
\mathrm{b}_{\text {Daughter of } \mathrm{Sr}-90 \text {; for the purpose of calculation, }} \\
\text { to decay coincident with parent decay. }\end{array}$} \\
\hline
\end{tabular}

The dose delivered by beta decay was calculated from the following equations. The dose delivered by the alpha decay of the Pu-239 was calculated using the same formulation as for beta decay. The initial beta dose rate of the ith radionuclide, $D_{i}$, is:

$$
\stackrel{\bullet B}{D_{i}}=A \quad C_{i} \bar{E}_{i}
$$




\author{
APPENDIX C, Continued \\ CUMULATIVE DOSE CALCULATIONS FOR THE \\ ALARA 1146 STRIPPABLE COATING SAMPLES FROM THE \\ TMI-2 REACTOR BUILDING GROSS DECONTAMINATION EXPERIMENT
}

$\mathrm{C}_{i}$ is the activity density of the $i$ th radionuclide, $\bar{E}_{i}$ is the average beta energy and $A$ is a proportionality constant. When $C_{\dot{f}}$ is in $\mathrm{mC} i / \mathrm{cm}^{3}$ and $\vec{E}_{i}$ is in MeV, A equals $2.1 \times 10^{3} \mathrm{rad} \mathrm{cm}^{3} \mathrm{MeV}^{-1} \mathrm{~h}^{-1} \mathrm{mCi}^{-1}$ and $D_{i}$ is obtained in rad per h. The total absorbed beta dose due to the decay of the ith radionuc lide, $\mathrm{D}_{i}^{\beta}(\infty)$, is

$$
\dot{D}_{i}^{\beta}(\infty)=\frac{\dot{D}_{j}^{\beta} \times 8.76 \times 10^{3} \mathrm{~h} \cdot \mathrm{yr}^{-1}}{\lambda i}
$$

where $\lambda_{i}$ is the decay constant of the $i$ th radionuclide in years ${ }^{-1}$. The beta dose absorbed at any time may then be calculated by

$$
D_{i}^{\beta}(t)=D_{i}^{\beta}(\infty)\left(1-e^{-\lambda_{i} t}\right)
$$

The dose delivered by gamma decay was estimated from the following equations. The gamma dose rate is

$$
D_{i}^{\gamma}=C_{i} \Gamma_{i} \bar{g}
$$

where $\Gamma_{i}$ is the gamma ray constant of the ith radionuclide and $\bar{g}$ is a geometric factor, which assumes tissue equivalency. $\Gamma_{i}$ has the units rad $\mathrm{cm}^{2} \mathrm{mCi}^{-1} \mathrm{~h}^{-1}, \overline{\mathrm{g}}$ has the unit $\mathrm{cm}^{-1}$.

The value of $\bar{g}=136$ was taken from the table of values of $\bar{g}$ given in Reference 2 for a cylinder of radius $=25 \mathrm{~cm}$ and height $=100 \mathrm{~cm}$.

The total gamma absorbed dose, $\mathrm{D}_{i}^{\gamma}(\infty)$, is

$$
D_{i}^{Y}(\infty)=\frac{D_{I}^{\gamma} \times 8.76 \times 10^{3} \mathrm{~h} \cdot \mathrm{yr}-1}{\lambda_{i}}
$$

and the cumulative'gamma dose was obtained from

$$
D_{i}^{\gamma}(t)=D_{i}^{\gamma}(\infty)\left(1-e^{-\lambda_{i} t}\right)
$$

The total cumulative absorbed dose for all nuclei and decay types is shown in Table C.2. 
CUMULATIVE DOSE CALCULATIONS FOR THE

ALARA 1146 STRIPPABLE COATING SAMPLES FROM THE

TMI-2 REACTOR BUILDING GROSS DECONTAMINATION EXPERIMENT

Table C.2

Total Absorbed Dose to the Average TMI Strippable Coating in 300 Years Assuming a 55-Ga1 Drum and the Activity Densities in Tables 4.6 and 4.7

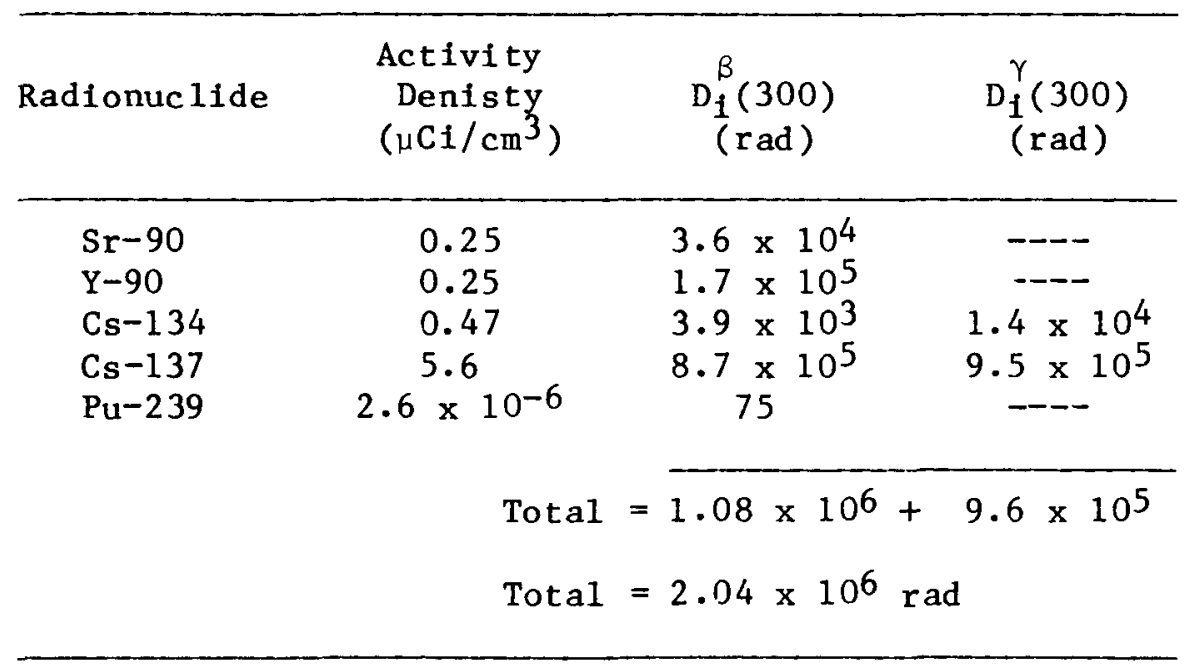

\section{References}

1. Bureau of Radiological Health and the Training Institute, Environmental Control Administration, Radiological Health Handbook, U.S. Government Printing office, Washington, D.C. (1970).

2. G. J. Hine and G. L. Brownel 1, Radiation Dosimetry, Academic Press, Inc. New York (1956). 


\begin{tabular}{|c|c|}
\hline $\begin{array}{l}\text { U.S. NUCLEAR REGULATORY COMMISSION } \\
\text { BIBLIOGRAPHIC DATA SHEET }\end{array}$ & $\begin{array}{l}\text { 1. REPORT NUMBER (Assigned by OOC) } \\
\text { NUREG/CR-3381 } \\
\text { BNL-NUREG-51689 }\end{array}$ \\
\hline \multirow{2}{*}{$\begin{array}{l}\text { 4. TITLE AND SUBTITLE (AdaVolume No, if appropriate) } \\
\text { Evaluation of Three Mile Island Unit } 2 \text { Reactor } \\
\text { Building Decontamination Process }\end{array}$} & 2. (Leave blank) \\
\hline & 3. RECIPIENT'S ACCESSION NO. \\
\hline 7. AUTHOR(S) & 5. DATE REPORT COMPLETED \\
\hline D. Dougherty, J.W. Adams & \begin{tabular}{c|c} 
MONTH & YEAR \\
May & 1983 \\
\end{tabular} \\
\hline 9. PERFORMING ORGANIZATION NAME AND MAILING ADDRESS (Include Zip Code) & DATE REPORT ISSUEO \\
\hline \multirow{3}{*}{$\begin{array}{l}\text { Brookhaven National Laboratory } \\
\text { Upton, NY } 11973\end{array}$} & \begin{tabular}{c|c|} 
MONTH & YEAR \\
AuquSt & 1983 \\
\end{tabular} \\
\hline & 6 (Leave blank) \\
\hline & 8 (Leave blank) \\
\hline \multirow{2}{*}{$\begin{array}{l}\text { 12. SPONSORING ORGANIZATION NAME AND MAILING ADDRESS (Include Zip Code) } \\
\text { Division of Waste Management } \\
\text { Office of Nuclear Materials Safety and Safeguards } \\
\text { U.S. Nuclear Regulatory Commission } \\
\text { Washington, D. C. } 20555\end{array}$} & 10. PROJECT/TASK/WORK UNIT NO. \\
\hline & $\begin{array}{l}11 \text { FIN NO. } \\
\text { A } 3162\end{array}$ \\
\hline
\end{tabular}

13. TYPE OF REPORT

PERIOD COVERED (/nclusive dates)

Technical

15. SUPPLEMENTARY NOTES

16. ABSTRACT (200 words or less)

Decontamination activities from the cleanup of the Three Mile Island Unit 2 Reactor Building are generating a variety of waste streams. Solid wastes being disposed of in commmercial shallow land burial include trash and rubbish, ionexchange resins (Epicor-II) and strippable coatings.

The radwaste streams arising from cleanup activities currently under way are characterized and classified under the waste classification scheme of 10 CFR Part 61. It appears that much of the Epicor-II ion-exchange resin being disposed of in commercial land burial will be class $B$ and require stabilization.

Strippable coatings being used at TMI-2 were tested for leachability of radionuclides and chelating agents, thermal stability, radiation stability, stability under immersion and biodegradability. Results indicated that both radionuclide contamination and chelating agents leach from strippable coating waste.

17. KEY WORDS AND DOCUMENT ANALYSIS

17d DESCRIPTORS

Decontamination, Radwaste, Ion-exchange resin, Strippable coatings, Waste classification

17b. IDENTIFIERS'OPEN-ENDED TERMS

18. AVAILABILITYY STATEMENT

Unlimited

\begin{tabular}{|c|c|}
\hline $\begin{array}{l}19 \text { SECURITY CLASS (This report) } \\
\text { Unclascified }\end{array}$ & 21 NO OF PAGES \\
\hline${ }^{20}$ SEClflTy Chass (This page) & $\begin{array}{c}22 \text { PRICE } \\
S\end{array}$ \\
\hline
\end{tabular}



UNITED STATES

NUCLEAR REGULATORY COMMISSION

WASHINGTON, D.C. 20555

OFFICIAL BUSINESS

PENALTY FOR PRIVATE USE, $\$ 300$

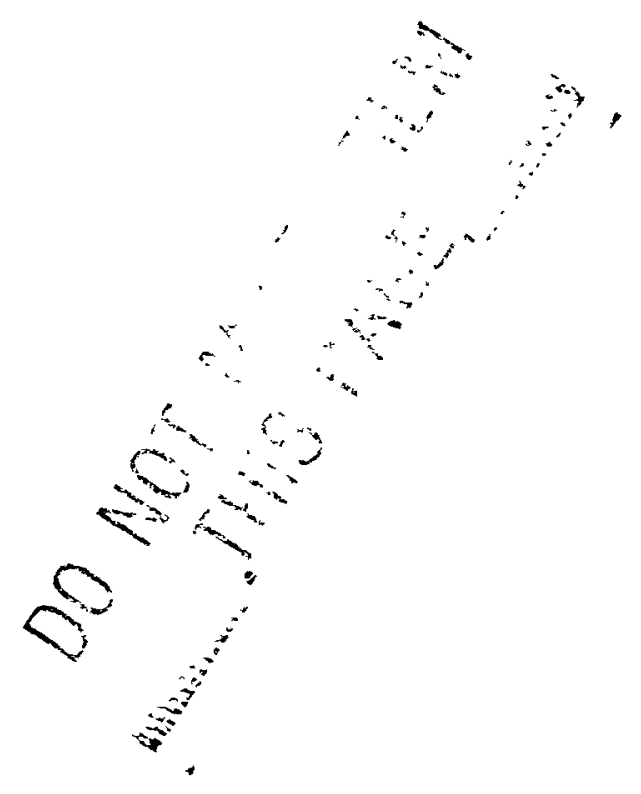

